\title{
Ultra-High Performance Concrete: Mechanical Performance, Durability, Sustainability and Implementation Challenges
}

\author{
S. Abbas ${ }^{1)}$, M. L. Nehdi ${ }^{2), *}$, and M. A. Saleem ${ }^{1)}$ \\ (Received January 4, 2016, Accepted May 30, 2016, Published online June 28, 2016)
}

\begin{abstract}
In this study, an extensive literature review has been conducted on the material characterization of UHPC and its potential for large-scale field applicability. The successful production of ultra-high performance concrete (UHPC) depends on its material ingredients and mixture proportioning, which leads to denser and relatively more homogenous particle packing. A database was compiled from various research and field studies around the world on the mechanical and durability performance of UHPC. It is shown that UHPC provides a viable and long-term solution for improved sustainable construction owing to its ultrahigh strength properties, improved fatigue behavior and very low porosity, leading to excellent resistance against aggressive environments. The literature review revealed that the curing regimes and fiber dosage are the main factors that control the mechanical and durability properties of UHPC. Currently, the applications of UHPC in construction are very limited due to its higher initial cost, lack of contractor experience and the absence of widely accepted design provisions. However, sustained research progress in producing UHPC using locally available materials under normal curing conditions should reduce its material cost. Current challenges regarding the implementation of UHPC in full-scale structures are highlighted. This study strives to assist engineers, consultants, contractors and other construction industry stakeholders to better understand the unique characteristics and capabilities of UHPC, which should demystify this resilient and sustainable construction material.
\end{abstract}

Keywords: ultra-high performance concrete, workability, mechanical properties, durability, sustainability, application.

\section{Introduction}

Ultra-high performance concrete (UHPC) is a novel construction material exhibiting enhanced mechanical and durability properties, which can lead to economical construction through reducing the cross-sections of structural members with associated materials savings and lower installation and labor costs (Tang 2004). The relatively high initial cost of UHPC has restricted its wider use in the construction industry. However, ongoing research and investigations are filling knowledge gaps in order to commence innovative UHPC having reduced initial cost.

Furthermore, the development and wide acceptance of an UHPC design code provisions should encourage stakeholders in the construction industry to implement large scale applications. This becomes even more relevant with the more recent push by organizations such as the American Concrete Institute, which identified using high-strength steel reinforcement in concrete as a top research priority. Combining UHPC and high-strength steel is expected to yield

\footnotetext{
${ }^{1)}$ Department of Civil Engineering, University of Engineering and Technology, Lahore, Pakistan.

${ }^{2)}$ Department of Civil and Environmental Engineering, Western University, London, ON, Canada.

*Corresponding Author; E-mail: mnehdi@uwo.ca Copyright ( $\odot$ The Author(s) 2016. This article is published with open access at Springerlink.com
}

unique structures in the near future. UHPC potential applications include tall structures, rehabilitation works, structural and non-structural elements, machine parts and military structures. Lighter weight structures owing to smaller crosssections can be made using UHPC. Therefore, UHPC can be effectively utilized in the precast concrete industry. Moreover, UHPC was widely used in pedestrian footbridges and highway bridges. For example, the first UHPC footbridge in Canada was constructed in 1997. In the United States, Wapello County Mars Hill was the first highway transportation bridge constructed with UHPC in 2006. In the Kinzua Dam Stilling Basin, UHPC was used for rehabilitation and strengthening purposes. Furthermore, architecturally and aesthetically appealing structures can be made using UHPC (Schmidt et al. 2004, 2012; Fehling et al. 2008). Table 1 summarizes some of the existing UHPC applications around the world. In the present study, an extensive review of literature on UHPC properties was conducted and summarized in tabular representation for a user friendly access to this scattered information.

\section{UHPC Composition}

The key factor in producing UHPC is to improve the micro and macro properties of its mixture ingredients to ensure mechanical homogeneity, maximum particle packing density and minimum size of flaws (Schmidt et al. 2005; Vernet 
2004; Shah and Weiss 1998; Wille et al. 2011; Shi et al. 2015). Table 2 shows the range of UHPC constituents used in various studies for the successful production of UHPC.

\subsection{Binders}

A relatively high proportion of cement is used in UHPC compared to that used in normal-strength (NS) and high-performance concrete (HPC) (Schmidt and Fehling 2005; Ghafari et al. 2015). It was observed that increasing the cement content increased the UHPC compressive strength; however, beyond an optimum cement content (around $1700 \mathrm{~kg} / \mathrm{m}^{3}\left(106 \mathrm{lb} / \mathrm{ft}^{3}\right)$, compressive strength tends to decline likely due to limited participation of aggregates (Talebinejad et al. 2004). Cement with moderate Blaine fineness $\left(4000 \mathrm{~cm}^{2} / \mathrm{g}\left(281,240 \mathrm{in}^{2} / \mathrm{lb}\right)\right)$ and tri-calcium aluminate $\left(\mathrm{C}_{3} \mathrm{~A}\right)$ content lower than $6 \%$ is preferred due to its lower water demand (Wille et al. 2011). Special micro-fine cements with particle size smaller than regular Portland cement were also used for developing UHPC (Strunge and Deuse 2008).

Because of the very low water/binder ratio $(\mathrm{w} / \mathrm{b})$ of UHPC, only part of the total cement hydrates and the unhydrated cement can be replaced with crushed quartz, fly ash or blast furnace slag. For instance, up to 30,36 and $40 \%$ by volume of cement in UHPC mixtures can be replaced with crushed quartz, blast furnace slag or fly ash, respectively, without compromising the compressive strength (Ma and Schneider 2002; Soutsos et al. 2005; Yazici 2006).

Moreover, the addition of silica fume as a binder can improve the workability of UHPC by filling voids between coarser particles owing to its much finer particle size and optimal spherical shape. In addition to this microfiller effect, silica fume also enhance the strength properties of UHPC through its pozzolanic reactions (Ma and Schneider 2002; Richard and Cheyrezy 1995). Various studies (Ma and Schneider 2002; Matte and Moranville 1999; Chan and Chu 2004; Xing et al. 2006) recommended silica fume dosages of $20-30 \%$ of the total binder material to achieve denser particle packing and pozzolanic reactivity in UHPC, leading to higher strength properties. For instance, $25 \%$ by cement weight of low carbon content $(<0.5 \%)$ silica fume was recommended as an optimum dosage in UHPC (Wille et al. 2011).

\subsection{Water/Binder Ratio}

A very low water/binder ratio $(\mathrm{w} / \mathrm{b})$ is used in UHPC mixtures. Minimum w/b of 0.08 was reported by Richard and Cheyrezy (1995); however, this ratio did not ensure dense particle packing. An optimum w/b ratio of $0.13-0.20$ was suggested in previous studies (Richard and Cheyrezy 1995; Larrard and Sedran 1994; Gao et al. 2006; Wen-yu et al. 2004; Shi et al. 2015) to achieve maximum relative density and spread flow. However, researchers (Wille et al. 2011; Droll 2004) also achieved compressive strength higher than $150 \mathrm{MPa}(22 \mathrm{ksi})$ using $0.25 \mathrm{w} / \mathrm{b}$. Therefore, it can be argued that the $\mathrm{w} / \mathrm{b}$ is not the sole strength governing parameter of UHPC. The curing regime, properties of mixture ingredients, mixing procedures and mixer type are also important parameters.

\subsection{Superplasticizer}

The reduced workability of UHPC due to its very low w/b can be resolved by adding effective superplasticizers (SP). The required SP dosage significantly depends on the compatibility between the mixture ingredients and the type of SP used. Improved compatibility can lead to lower SP dosage. For example, an UHPC mixture incorporating a limestone micro-filler is more workable and compatible compared to a mixture incorporating higher surface area metakaolin at the same SP dosage (Rougeau and Burys 2004). Furthermore, stepwise or delayed addition of SP (rather than adding the SP at once) was found to enhance the workability of UHPC mixtures owing to an improved dispersing effect (Tue et al. 2008). Various studies (Schmidt et al. 2004, 2012; Fehling et al. 2008) used SP dosages ranging between 1 and $8 \%$ by cement weight for enhancing the workability of UHPC mixtures. Generally, SP dosages of $1.4-2.4 \%$ by cement weight are recommended (Wille et al. 2011).

\subsection{Aggregates}

Generally, failure in conventional concrete is initiated by damage at the interfacial transition zone (ITZ) between the cementitious matrix and aggregates (Jun et al. 2008). Therefore, eliminating coarse aggregates in UHPC mixtures reduces such weaknesses induced by such ITZ. In addition, mitigating the ITZ flaws results in overall lower porosity in the matrix, leading to enhanced mechanical strength (Mehta et al. 2006). The fine aggregate like quartz sand plays an important role in reducing the maximum paste thickness (MPT), which is also a key factor in the mixture design of UHPC. An optimum sand-to-cement ratio was found to be 1.4 for a quartz particle size of $0.8 \mathrm{~mm}(0.031 \mathrm{in})$ (Wille et al. 2011).

\subsection{Steel Fibers}

Due to its very high strength and homogeneity, UHPC is very brittle; yet it can be made ductile by adding steel fibers (Bayard and Ple 2003; Graybeal 2006; Wang et al. 2015). The most commonly used size of steel fibers is $13 \mathrm{~mm}(0.5$ in) in length and $0.20 \mathrm{~mm}$ (0.008 in) in diameter (Schmidt et al. 2004, 2012; Fehling et al. 2008). Richard and Cheyrezy (1995) recommended using $2 \%$ by mixture volume of steel fibers for an economical and workable UHPC mixture design.

\subsection{Nano-materials}

The success of mixture design of UHPC is highly dependent on achieving highest particle packing density and ultra-high consolidation of the concrete matrix. Therefore, the addition of nano particles produced from silicon dioxide $\left(\mathrm{SiO}_{2}\right)$, aluminum oxide $\left(\mathrm{Al}_{2} \mathrm{O}_{3}\right)$, iron oxide $\left(\mathrm{Fe}_{2} \mathrm{O}_{3}\right)$, titanium dioxide $\left(\mathrm{TiO}_{2}\right)$ or zirconium dioxide $\left(\mathrm{ZrO}_{2}\right)$ can fill the gaps between micron-sized cementitious materials and fine aggregates, leading to reduced porosity and higher particle packing density. Nano-materials can also accelerate cement hydration via a nucleation and growth mechanism, stimulate the formation of additional calcium silicate hydrates $(\mathrm{C}-\mathrm{S}-$ 
Table 1 Example applications of UHPC around the world.

\begin{tabular}{|c|c|c|c|c|}
\hline Structures/applications & Location & Completion/production year & $\begin{array}{c}\text { Compressive strength } \\
(\mathrm{MPa})\end{array}$ & Flexural strength $(\mathrm{MPa})$ \\
\hline Sherbrooke footbridge & Sherbrooke, Canada & 1997 & 200 & 40 \\
\hline Joppa clinker silo & Illinois, USA & 2001 & 220 & 50 \\
\hline Seonyu footbridge & Seoul, Korea & 2002 & 180 & 32 \\
\hline Sakata Mirai footbridge & Sakata, Japan & 2002 & 238 & 40 \\
\hline Millau Viaduct toll gate & A75 Motorway, France & 2004 & 165 & 30 \\
\hline Shepherds creek bridge & Sydney, Australia & 2005 & 180 & - \\
\hline Blast resisting panels & Melbourne, Australia & 2005 & 160 & 30 \\
\hline Papatoetoe footbridge & Auckland, New Zealand & 2006 & 160 & 30 \\
\hline Glenmore/Legsby bridge & Calgary, Canada & 2007 & - & - \\
\hline Gaertnerplatz bridge & Kassel, Germany & 2007 & 150 & 35 \\
\hline UHPC girder bridge & Iowa, USA & 2008 & 150 & - \\
\hline Wind turbine foundations & Denmark & 2008 & 210 & 24 \\
\hline Haneda Airport slabs & Tokyo, Japan & 2010 & 210 & 45 \\
\hline Whiteman Creek bridge & Brantford, Canada & 2011 & 140 & 30 \\
\hline Sewer pipes & Germany & 2012 & 151 & - \\
\hline Spun concrete columns & Germany & 2012 & 179 & - \\
\hline UHPC truss footbridge & Spain & 2012 & 150 & - \\
\hline
\end{tabular}

Data collected from Schmidt et al. (2004, 2012), Fehling et al. (2008) and Talebinejad et al. (2004).

H) through possible pozzolanic reactions, and reduce calcium leaching and weak zones of calcium hydroxide (Droll 2004; Sobolev and Amirjanov 2004; Bjornstrom et al. 2004; Korpa and Trettin 2007). This can cause significant improvements in mechanical and durability properties of UHPC (Ghafari et al. 2012). Researchers (Ghafari et al. 2012; Shakhmenko et al. 2012) recommended using 1-5\% by cement weight of nano-particles in UHPC mixture design for successful improvement of UHPC material properties.

Ghafari et al. (2014) reported an increase in compressive strength of UHPC with higher dosage of nano-silica (nS). An optimum amount of $\mathrm{nS}$ was reported to be $3.74 \%$ by binder mass (Rong et al. 2015; Yu et al. 2014). Moreover, it was observed that the addition of $\mathrm{nS}$ in UHPC mixtures decreased the corrosion rate of steel rebar (Ghafari et al. 2015). It was also reported that UHPC mixtures incorporating $\mathrm{nS}$ showed reduction in capillary porosity compared to that of UHPC mixtures without nS (Ghafari et al. 2012, 2014). Fadzil et al. $(2013,2014)$ used $1 \%$ of nano metakaolin and observed enhanced microstructure of UHPC leading to reduced chloride ions penetration in UHPC. Incorporating nano $\mathrm{CaCO}_{3}$ in UHPC improved the hydration process at early-age, producing denser particle packing, and improving mechanical properties ( $\mathrm{Li}$ et al. 2015). Huang and Cao (Huang and Cao 2012) used nano- $\mathrm{CaCO}_{3}$ and observed a $17 \%$ increase in compressive strength compared to that of the control UHPC specimens. Falikman et al. (Falikman et al. 2012) reported smog eating and self-healing properties of UHPC incorporating nano $\mathrm{TiO}_{2}$ particles through a photocatalysis effect. It was observed that mixtures incorporating nano $\mathrm{Fe}_{2} \mathrm{O}_{3}$ increased the mechanical strength of UHPC and induced self-sensing abilities ( $\mathrm{Li}$ et al. 2004). Furthermore, carbon nanotubes and nanofibers can be used in UHPC for further improving its mechanical properties. Therefore, it can be concluded that the use of nano materials in UHPC can lead to a denser microstructure and better mechanical and durability performance.

\section{Mixture Design of UHPC}

The mixture design of UHPC should be economical and sustainable for achieving denser matrix, reduced porosity and improved internal microstructure, leading to superior mechanical and durability properties. Various models have been reported for the mixture design of UHPC. For instance, Larrad and Sedran (1994) proposed a linear packing density model (LPDM) for the mixture design of UHPC. However, the LPDM model did not focus on the relationship between materials proportions and packing density due to the linear nature of LPDM model. Therefore, this model was improved considering the virtual density theory and a new model known as solid suspension model (SSM) was developed (Larrard and Sedran 1994). Afterwards, based on the compaction index concept and virtual packing density, the compressible packing model (CPM) for the mixture design 
Table 2 Typical composition of UHPC.

\begin{tabular}{c|c}
\hline UHPC constituents & Range (\% by weight) \\
\hline Cement & $27-40$ \\
\hline Silica fume & $6-12$ \\
\hline Quartz powder & $7-14$ \\
\hline Sand & $35-45$ \\
\hline Superplasticizer & $0.5-3$ \\
\hline Water & $4-10$ \\
\hline Steel fiber & $0-8$ \\
\hline
\end{tabular}

Data collected from Schmidt et al. (2004, 2012), Fehling et al. (2008) and Talebinejad et al. (2004).

Table 3 Effect of $w / b$ and superplasticizer on air content of UHPC.

\begin{tabular}{c|c|c|c}
\hline References & w/b & Superplasticizer & Air content (\%) \\
\hline \hline Ingo et al. (2004) & 0.25 & - & 4.3 \\
\hline Maeder et al. (2004) & 0.18 & $45 \mathrm{~kg} / \mathrm{m}^{3}$ & 3.5 \\
\hline Kamen et al. (2009) & 0.13 & $46 \mathrm{~kg} / \mathrm{m}^{3}$ & 1.8 \\
\hline Pierard and Cauberg (2009) & 0.17 & $20 \mathrm{~kg} / \mathrm{m}^{3}$ & 1.0 \\
\hline Pierard et al. (2012) & 0.11 & $15 \mathrm{~kg} / \mathrm{m}^{3}$ & 2.5 \\
\hline Magureanu et al. (2012) & 0.13 & $52 \mathrm{~kg} / \mathrm{m}^{3}$ & 4.6 \\
\hline
\end{tabular}

of UHPC was proposed (Larrard and Sedran 2002). Yu et al. (2014) optimized the mixture ingredients of UHPC using a modified Andreasen and Andersen model with various distribution modules.

Geisenhansluke and Schmidt (2004) designed a locally produced UHPC mixture based on particle shape, size and density. Moreover, it was reported that the cement content can be lessened by utilizing multi-grained fine particles. An ecological UHPC mixture was developed by Fennis et al. (2009) based on particle packing technology, which reduced the cement content by $50 \%$. A robust mixture design of UHPC was proposed by Lohas and Ramge (Lohaus and Ramge 2008) based on superplasticizer for achieving desired workability of the paste depending on the water-to-powder ratio. Wille et al. (Wille et al. 2011) developed UHPC using local materials without any special type of mixer and heat treatment based on spread flow properties. Using a modified Andreasen and Andersen particle packing model, a densely compacted UHPC was developed with a cement content lower than $675 \mathrm{~kg} / \mathrm{m}^{3}$ (Yu et al. 2014).

Furthermore, statistical models were also proposed for the mixture design of UHPC. For example, adaptive neuro fuzzy interface system (ANFIS) was used for proportioning the mixture ingredients of UHPC (Taghaddos et al. 2004). A response surface methodology (RSM) was adopted by Ghafari et al. (2014) for predicting the maximum flexural strength of self-compacting steel fiber-reinforced UHPC with varying steel fiber contents. In another study, Ghafari et al. (2015) used a statistical mixture design (SMD) model for optimizing the mixture design of UHPC. The effect of individual ingredients and their interactions were studied for predicting the compressive strength of UHPC using minimum cement content (Ghafari et al. 2015). Moreover, artificial neural network (ANN) models were developed for predicting the performance of UHPC under different curing conditions (Ghafari et al. 2012, 2015). It was found that the polynomial regression model was suitable for predicting the desired properties of UHPC mixtures (Ghafari et al. 2014, 2015). The optimum amount of cement and silica fume was 24 and $9 \%$ by volume of concrete respectively, based on ANN models analysis (Ghafari et al. 2015). Ghafari et al. $(2012,2015)$ concluded that the ANN model was more efficient compared to the SMD approach for the characterization of UHPC material properties. Van and Ludwig (2012) designed UHPC mixtures using the D-optimal design technique and reported a good correlation with experimental results.

\section{Fresh Properties of UHPC}

\subsection{Air Content}

The reported air content in UHPC mixtures ranged from 0.3 to $5.4 \%$ by mixture volume depending on the mixture design (Wille et al. 2011). Higher $\mathrm{w} / \mathrm{b}$ and SP dosage tend to increase the air content in UHPC mixtures (Table 3). Furthermore, the total air content is highly dependent on the type of mixer used (Ingo et al. 2004). For instance, laboratory mixers with higher mixing speed lead to sticky consistency of the paste, consequently increasing the air content 
Table 4 Conversion factors for various type and size of UHPC specimens for compressive strength.

\begin{tabular}{c|c|c}
\hline References & Specimen type and size & Conversion factor \\
\hline \hline \multirow{2}{*}{ Skazlic et al. (2008) } & Cylinder, $(70 \times 140 / 100 \times 200)$ & $1.05-1.15$ \\
\cline { 2 - 3 } & Cylinder, $(150 \times 300 / 100 \times 200)$ & $0.85-0.95$ \\
\hline \multirow{2}{*}{ Graybeal and Davis (2008) } & Cylinder 76/cube 100 & 0.94 \\
\cline { 2 - 3 } & Cylinder 76/cube 71 & 0.96 \\
\cline { 2 - 3 } & Cylinder 76/cube 51 & 1.01 \\
\cline { 2 - 3 } & Cylinder 76/cylinder 102 & 1.09 \\
\cline { 2 - 3 } & Cube, (50/100) & 1.14 \\
\cline { 2 - 3 } & Cube 50/cylinder 100 & 1.09 \\
\cline { 2 - 3 }
\end{tabular}

(typically $4.3 \%$ ). On the other hand, ring type mixers for instance in precast plants apply high shear forces, leading to relatively lower air content (approximately $3.2 \%$ ) for the same mixture composition and proportions (Ingo et al. 2004). It was reported that an air content in UHPC of below $1 \%$ can be achieved using a vacuum accessory with pressure of 50 mbar (Ingo et al. 2004). Also, the concrete placement method significantly affects the air content. For instance, concrete placement into formwork using spiral pump reduced the air content from 2.9 to $1.3 \%$ (Ingo et al. 2004). Furthermore, the delayed addition of SP decreased the viscosity of the UHPC mixture and consequently reduced the air content from 2.5 to $1 \%$ (Tue et al. 2008). A threshold value of $2 \%$ air content by mixture volume was considered adequate for improved spread flow and enhanced properties of UHPC mixtures (Wille et al. 2011).

\subsection{Setting Time}

According to Habel et al. (2006), the setting time of UHPC is defined as "the time when the mixture attains a stiffness of $1000 \mathrm{MPa}(145 \mathrm{ksi})$ and autogenous shrinkage initiates". In another study, Graybeal (2006) defined the initial setting time as "a penetration resistance of $3.45 \mathrm{MPa}$ $(0.5 \mathrm{ksi})$ at $15 \mathrm{~h}$ after casting" and the final setting time as "a penetration resistance of $27.60 \mathrm{MPa}(4 \mathrm{ksi})$ at about $18-20 \mathrm{~h}$ after casting” based on AASHTO T197 (2000). Generally, the reported setting time of UHPC ranged from 6 to $12 \mathrm{~h}$ depending on the mixture design (Richard and Cheyrezy 1995; Yoo et al. 2013; Kazemi and Lubell 2012). However, some studies (Brown 2006; Graybeal 2007; Habel 2004; Morin et al. 2001) showed that the setting time for UHPC can be delayed for up to $30-40 \mathrm{~h}$ due to the set retarding effect of high SP dosage. Furthermore, it was observed that surface covering of freshly mixed UHPC delayed its setting time (Yoo et al. 2013).

\subsection{Workability}

The handling of UHPC during casting is a major problem due to its low w/b and reduced workability. The workability of UHPC is also affected by the addition of steel fibers. Studies showed that UHPC mixtures incorporating fibers with smaller aspect ratio are more workable even at higher fiber dosage compared to that of mixtures with fibers having larger aspect ratio. For instance, $6 \mathrm{~mm}$ (0.25 in) long and $0.15 \mathrm{~mm}(0.006 \mathrm{in})$ diameter steel fibers can be used up to $10 \%$ by mixture volume, while $12 \mathrm{~mm}$ ( $0.5 \mathrm{in})$ long and $0.15 \mathrm{~mm}(0.006 \mathrm{in})$ diameter fibers can be used up to $3 \%$ by mixture volume without affecting the mixture workability (Wille et al. 2011; Rossi 2005). Wille et al. (2011) recommended adopting 200-350 mm (8-14 in) limit for the flow diameter spread according to ASTM C230 (1998) for dense UHPC without fibers. Furthermore, the spread flow can be increased by utilizing ultra-fine or nano-particle materials. For example, a $16 \%$ increase in spread flow was observed with the addition of $1 \%$ by cement weight of nano-silica (Shakhmenko et al. 2012).

\section{Mechanical Properties}

\subsection{Compressive Strength}

\subsubsection{Effect of Specimen Size and Shape}

It was found that the specimen size has a significant influence on the measured compressive strength of UHPC. For instance, Skazlic et al. (2008) observed $21 \%$ increase in cylinder compressive strength for a specimen size of $70 \times 140 \mathrm{~mm}(2.75 \times 5.50$ in $)$ compared to that of $100 \times 200 \mathrm{~mm}(3.94 \times 7.87 \mathrm{in})$. This is likely due to the higher probability of encountering larger size flaws in larger specimens (Graybeal 2006; Ahlborn et al. 2008). Moreover, it was observed that cube specimens exhibited higher strength compared to that of cylindrical specimens due to the wellknown confinement effect of the testing machine platens (Kazemi and Lubell 2012; Graybeal and Davis 2008). Table 4 shows proposed conversion factors for various UHPC specimen types and sizes. Using $70 \mathrm{~mm}$ (2.75 in) cube specimens was recommended considering the machine capacity and cylinder end grinding concerns (Graybeal and Davis 2008). 
Table 5 Effect of pressure application on UHPC compressive strength.

\begin{tabular}{c|c|c|c}
\hline References & Heat treatment $\left({ }^{\circ} \mathrm{C}\right)$ & Pressure application (MPa) & Compressive strength (MPa) \\
\hline \hline Roy et al. (1972) & 250 & 50 & 510 \\
\hline Richard and Cheyrezy (1995) & 400 & 50 & 800 \\
\hline Roux et al. (1996) & 20 & 60 & 230 \\
\hline Shaheen and shrive (2006) & 300 & 26 & 280 \\
\hline
\end{tabular}

\subsubsection{Effect of Pre-treatment}

The rate of hydration in UHPC mixtures can be increased through proper heat treatment. The application of thermal treatment advances pozzolanic reactions, leading to formation of additional calcium silicate hydrates $(\mathrm{C}-\mathrm{S}-\mathrm{H})(\mathrm{Heinz}$ and Ludwig 2004; Muller et al. 2008). These C-S-H phases fill small pores, leading to denser microstructure and consequently higher mechanical properties (Graybeal 2006; Muller et al. 2008; Collepardi et al. 1997; Cwirzen 2007; Lee and Chisholm 2005). The rate of cement hydration reactions increases at higher heat treatment temperature. For example, hydration products formation increased from 10 to $55 \%$ at $8 \mathrm{~h}$ when the temperature was raised from 90 to $250{ }^{\circ} \mathrm{C}\left(194-482{ }^{\circ} \mathrm{F}\right)$ (Zanni et al. 1996). Generally, the heat treatment typically applied for UHPC specimens is from 90 to $400{ }^{\circ} \mathrm{C}\left(194-752{ }^{\circ} \mathrm{F}\right.$ ) for 2-6 days (Graybeal 2006; Heinz and Ludwig 2004; Richard and Cheyrezy 1994; Teichmann and Schmidt 2004). A $40 \%$ average increase in compressive strength was observed for $90{ }^{\circ} \mathrm{C}\left(194{ }^{\circ} \mathrm{F}\right)$ heat treatment compared to that of untreated control specimens (Soutsos et al. 2005; Xing et al. 2006; Bonneau et al. 1997). The time of starting the thermal treatment had an insignificant effect on the UHPC compressive strength (Ahlborn et al. 2008). For instance, only $4 \%$ difference in compressive strength was observed for UHPC specimens thermally cured for 2 days right after demolding, compared to when the thermal treatment was applied after 10 days from demolding (Ahlborn et al. 2008). This should allow the pre-caster in fabricating various elements at different timelines and curing them together, leading to energy savings. Furthermore, during the setting of UHPC, the application of a confining pressure contributes towards increased compactness and denser microstructure, thus leading to higher strength and durability properties (Table 5). This can be attributed to the removal of entrapped air voids and free water (Richard and Cheyrezy 1995; Cwirzen et al. 2008).

\subsubsection{Effect of Steel Fibers}

It was observed that the addition of steel fibers changes the failure mode of UHPC specimens from complete damage or sudden explosion to a somewhat ductile behavior where specimens can remain intact without chipping and spalling (El-Dieb 2009). Various researchers (Reda et al. 1999; Schmidt et al. 2003) reported that the UHPC compressive strength was not influenced by the addition of high dosages of steel fibers. Increased concentration of steel fibers can create fiber bundling, thus leading to weak spots, which can reduce the efficiency of fibers, hence decreasing compressive strength. A slight increase in compressive strength due to fiber addition can be observed if proper thermal treatment is applied (Soutsos et al. 2005; Jun et al. 2008; Bonneau et al. 1997; Herold and Muller 2004). This mainly depends on the type of fibers and their dosage (Soutsos et al. 2005; Bonneau et al. 1997; Herold and Muller 2004). For example, approximately $30 \%$ increase in compressive strength was observed with the addition of $2.5 \%$ by mixture volume of steel fibers when specimens were subjected to thermal treatment (Soutsos et al. 2005; Graybeal 2006; Lee and Chisholm 2005; Bonneau et al. 1997). This increase in UHPC compressive strength was attributed to the enhanced tolerance of lateral strains owing to steel fiber addition (Kazemi and Lubell 2012; Hassan et al. 2012; Orgass and Klug 2004; Magureanu et al. 2012; Ye et al. 2012). Furthermore, it was reported that the addition of fibers resulted in less entrapped air, leading to improved density and hence higher compressive strength (Abbas et al. 2015).

\subsubsection{Effect of Casting Direction}

No significant effect of the casting direction was observed on the compressive strength of UHPC. For instance, Stiel et al. (2004) reported a compressive strength difference of less than $2 \%$ for UHPC cube specimens when loaded perpendicular and parallel to the casting direction.

\subsubsection{Effect of Loading Rate}

Due to its high compressive strength, more time is required to break UHPC specimens at low loading rate. For instance, a $150 \times 300 \mathrm{~mm}(6 \times 12$ in $)$ UHPC cylinder broke after $13 \mathrm{~min}$ when a $0.24 \mathrm{MPa} / \mathrm{s}$ (35 psi/s) loading rate was applied. Therefore, higher loading rate up to $1.0 \mathrm{MPa} / \mathrm{s}(150 \mathrm{psi} / \mathrm{s})$ can be applied without significantly affecting the strength properties of UHPC in order to reduce the failure time (Kazemi and Lubell 2012; Graybeal et al. 2003). According to AFGC-SETRA (2002) guidelines, a loading rate ranging between 0.24 and $1.7 \mathrm{MPa} / \mathrm{s}$ (35-250 $\mathrm{psi} / \mathrm{s}$ ) affected the UHPC compressive strength by less than $4 \%$.

\subsection{Elastic Modulus}

The compressive stress-strain curve of UHPC typically shows a linear elastic portion up to $80-90 \%$ of the maximum stress value (Graybeal 2007; Cheyrezy 1999). It was observed that the addition of fibers in UHPC did not significantly influence its elastic modulus. For example, only $7 \%$ increase in the elastic modulus was observed with the addition of $2 \%$ by mixture volume of steel fibers compared 
Table 6 Relationship between elastic modulus and compressive strength of UHPC.

\begin{tabular}{c|c}
\hline References & Models \\
\hline \hline ACI 363R-92 (HPC) (1997) & $E=3300 \cdot \sqrt{f_{c}^{\prime}+6.9}$ \\
\hline Ma and Schneider (2002) & $E=16,364 \cdot \ln \left(f_{c}^{\prime}\right)-34,828$ \\
\hline Sritharan et al. (2003) & $E=4150 \cdot \sqrt{f_{c}^{\prime}}$ \\
\hline Ma et al. (2004) & $E=19,000 \cdot \sqrt[3]{f_{c}^{\prime} / 10}$ \\
\hline Graybeal (2007) & $E=3840 \cdot \sqrt{f_{c}^{\prime}}$ \\
\hline
\end{tabular}

to that of control UHPC without fibers (Bonneau et al. 1996). Furthermore, the elastic modulus of UHPC is a function of heat treatment (Graybeal 2006; Graybeal 2007; Richard and Cheyrezy 1994). For instance, the modulus increased from 57 to $70 \mathrm{GPa}$ when specimens were subjected to a high temperature of $250{ }^{\circ} \mathrm{C}\left(482^{\circ} \mathrm{F}\right)$ for 2 days (Richard and Cheyrezy 1994). Various models that relate the elastic modulus and compressive strength of UHPC are shown in Table 6.

\subsection{Flexural Strength}

UHPC exhibits high flexural strength properties due to its dense particle packing and steel fiber addition (Graybeal et al. 2003; Kim et al. 2008). Researchers (Cheyrezy et al. 1998; Perry and Zakariasen 2004) reported flexural strength values of up to $48 \mathrm{MPa}$ (7.0 ksi) for UHPC depending on its mixture design and curing regime.

\subsubsection{Effect of Sample Preparation Technique and Concrete Pouring Direction}

No significant effect of the casting direction on the initial stiffness of UHPC beams subjected to bending was observed (Steil et al. 2004). However, it was reported that vertically cast beam specimens showed almost five times lower flexural strength compared to horizontally cast beam specimens (Steil et al. 2004). This was attributed to the difference in fiber orientation. Fibers were oriented perpendicular and parallel to the crack surface for horizontally and vertically cast beams, respectively. It was also observed that the failure surface was smoother for vertically cast beams, whereas horizontally cast beams showed rougher and wrinkled failure surfaces (Steil et al. 2004).

Moreover, the flexural strength of UHPC was also dependent on the pouring method of concrete into molds (Table 7). For instance, the pouring of concrete from one end of the mold only showed an increased flexural strength by $56 \%$ compared to that of the same concrete poured at different locations into the mold (Lappa et al. 2004). This was attributed to the strong fiber orientation (higher number of fibers crossing at particular sections) parallel to the flow direction (Lappa et al. 2004; Pansuk et al. 2008). Furthermore, Wille and Parra-Montesinos (2012) observed that beam specimens cast only at their middle point exhibited lower peak strength compared to that of similar specimens cast in layers with higher chute speed $(0.50 \mathrm{~m} / \mathrm{s}(20 \mathrm{in} / \mathrm{s}))$. A funnel like pattern was observed for beams cast only at the

Table 7 Effect of casting method on flexural capacity of UHPC.

\begin{tabular}{|c|c|c|c|c|c|}
\hline \multirow[t]{2}{*}{ References } & \multicolumn{2}{|c|}{ Steel fiber } & \multirow[t]{2}{*}{ Curing conditions } & \multirow{2}{*}{$\begin{array}{l}\text { Casting direction/ } \\
\text { pouring method }\end{array}$} & \multirow{2}{*}{$\begin{array}{c}\text { Flexural strength } \\
(\mathrm{MPa})\end{array}$} \\
\hline & $\mathrm{L} / \mathrm{D}(\mathrm{mm} / \mathrm{mm})$ & $(\%)$ & & & \\
\hline \multirow[t]{2}{*}{ Steil et al. (2004) } & \multirow[t]{2}{*}{$6 /-+13 /-$} & \multirow[t]{2}{*}{$5+1$} & \multirow{2}{*}{$\begin{array}{c}90{ }^{\circ} \mathrm{C} \text { in water tank for } \\
7 \text { days }\end{array}$} & Horizontal & 49.6 \\
\hline & & & & Vertical & 11.7 \\
\hline \multirow[t]{2}{*}{ Lappa et al. (2004) } & \multirow[t]{2}{*}{$20 / 0.3$} & \multirow[t]{2}{*}{2.5} & \multirow[t]{2}{*}{$\begin{array}{c}\text { Fog room at } 99 \% \mathrm{RH} \\
\text { until } 28 \text { days }\end{array}$} & $\begin{array}{c}\text { Concrete pouring at } \\
\text { one end only }\end{array}$ & 29.8 \\
\hline & & & & $\begin{array}{l}\text { Concrete pouring at } \\
\text { different locations }\end{array}$ & 19.1 \\
\hline \multirow[t]{2}{*}{ Kim et al. (2008) } & \multirow[t]{2}{*}{$15 /-$} & \multirow[t]{2}{*}{2} & \multirow[t]{2}{*}{-} & $\begin{array}{c}\text { Longitudinal (parallel } \\
\text { to flexural tension) }\end{array}$ & 72.0 \\
\hline & & & & $\begin{array}{c}\text { Vertical (perpendicular } \\
\text { to flexural tension) }\end{array}$ & 42.0 \\
\hline \multirow[t]{2}{*}{ Yang et al. (2010) } & \multirow[t]{2}{*}{$13 / 0.2$} & \multirow[t]{2}{*}{2} & \multirow{2}{*}{$\begin{array}{c}90{ }^{\circ} \mathrm{C} \text { for } 3 \text { days and } \\
20{ }^{\circ} \mathrm{C} \text { wet curing } \\
\text { thereafter }\end{array}$} & End casting of beams & 62.6 \\
\hline & & & & $\begin{array}{l}\text { Middle casting of } \\
\text { beams }\end{array}$ & 54.0 \\
\hline \multirow{2}{*}{$\begin{array}{l}\text { Wille and Parra- } \\
\text { Montesinos (2012) }\end{array}$} & \multirow[t]{2}{*}{$13 / 0.2$} & \multirow[t]{2}{*}{1.50} & \multirow{2}{*}{$\begin{array}{l}\text { Stored in water at } \\
20{ }^{\circ} \mathrm{C}\end{array}$} & Middle casting & 15.8 \\
\hline & & & & Layer casting & 21.8 \\
\hline
\end{tabular}

$L / D$ length $(\mathrm{mm}) /$ diameter $(\mathrm{mm})$. 
middle point, leading to arranging the fibers along the funnel. However, the beams cast in layers with higher chute speed $(0.50 \mathrm{~m} / \mathrm{s}(20 \mathrm{in} / \mathrm{s}))$ formed strong thin layers and desired fiber alignment along the beam axis, thus achieving increased flexural strength (Wille and Parra-Montesinos 2012). On the other hand, beams cast with lower chute speed $(0.13 \mathrm{~m} / \mathrm{s}(5 \mathrm{in} / \mathrm{s}))$ exhibited lower flexural strength compared to that of specimens cast at their middle only. This was attributed to the fact that the slow movement of chute formed thick layers of snake like pattern, leading to vertical orientations of fibers, consequently reducing the flexural strength (Wille and Parra-Montesinos 2012). It was observed that the concrete pouring location is also an important factor in achieving higher flexural strength (Table 7). For example, beams cast from the mold end exhibited $16 \%$ higher flexural strength compared to that of beams cast at the middle of the mold (Yang et al. 2010). This was ascribed to better flow properties of beams cast from the mold end, leading to improved fiber orientation and hence increased flexural strength (Yang et al. 2010).

\subsubsection{Effect of Fibers}

It was observed that fibers significantly affect the UHPC flexural properties (Kazemi and Lubell 2012; Magureanu et al. 2012). The flexural strength of UHPC increased linearly with increased fiber dosage (Kang et al. 2010) (Table 8 ). An increase in flexural strength by $144 \%$ was observed with $2.5 \%$ by mixture volume of steel fibers addition compared to that of control beams without fibers (Magureanu et al. 2012). The main role of fibers is to prevent the intergrowth of micro-cracks by absorbing tensile stresses, and consequently macro-cracks are prevented (Orgass and Klug 2004). Moreover, beam specimens incorporating fibers showed multiple cracks and exhibited steadier drop in load carrying capacity rather than a sudden drop in load after formation of the first crack (Kazemi and Lubell 2012). The failure was characterized by a single vertical macro-crack with multiple micro-cracks for UHPC incorporating steel fibers (Orgass and Klug 2004).

Furthermore, it was observed that the flexural capacity of UHPC was also dependent on the aspect ratio of fibers. For instance, UHPC mixtures incorporating higher aspect ratio fibers had increased flexural capacity compared to that of those with lower aspect ratio fibers. This was attributed to the fact that mixtures incorporating small diameter fibers (higher aspect ratio) have increased number of fibers per unit volume of concrete, leading to more fibers bridging cracks, and hence increased flexural capacity (Ye et al. 2012). Furthermore, a hybrid mixture of steel and polyvinyl alcohol (PVA) fibers significantly improved the flexural behavior of UHPC compared to their individual addition (Bornemann and Faber 2004). It was also observed that alkali resistant (AR) glass fibers improved the peak load carrying capacity by increasing the energy required for the development of micro-cracks. However, a reduction in ductility using ARglass fibers was observed compared to that for steel fibers (Lohaus and Anders 2004).

\subsubsection{Effect of Specimen Size}

The flexural strength of UHPC decreased as the specimen size increased (Table 8). For instance, a specimen size of $700 \times 150 \times 150 \mathrm{~mm}(27.50 \times 5.90 \times 5.90$ in $)$ showed a $33 \%$ decrease in flexural strength compared to that of a similar specimen with a size of $160 \times 40 \times 40 \mathrm{~mm}$ $(6.30 \times 1.57 \times 1.57$ in $)$ (Bornemann and Faber 2004). This was ascribed to the higher wall effect of fibers in smaller specimens (Kazemi and Lubell 2012; Magureanu et al. 2012; Wille and Parra-Montesinos 2012; Kooiman 2000). It was observed that the fiber orientation near the mold surfaces had two dimensional (2-D) patterns which changed to three dimensional (3-D) patterns away from the mold surfaces (Reineck and Greiner 2004). The 3-D fiber orientation is not favorable for higher flexural strength due to smaller equivalent fiber contents in the direction of flexural stresses. The smaller specimens have more tendency to form favorable 2-D patterns along the cross-section, leading to higher flexural strength (Kazemi and Lubell 2012; Reineck and Greiner 2004). It was also observed that the smaller beam specimens showed higher ductility compared to that of the larger specimens. This was attributed to the improved fiber orientation in the smaller specimens (Orgass and Klug 2004). Furthermore, it was reported that the average number of cracks and their spacing decreased as the specimen size decreased (Nguyen et al. 2013). This was directly related to their increased flexural tensile strain capacity (Nguyen et al. 2013). AFGC-SETRA (2002) recommended a reduction factor of $9 \%$ when the specimen height increases from $100 \mathrm{~mm}$ (3.97 in) to $150 \mathrm{~mm}(5.90 \mathrm{in})$.

\subsubsection{Effect of End Supports}

It was observed that UHPC beam specimens tested under high frictional support exhibited 30-60\% higher flexural capacity, depending on the fiber dosage, compared to that of similar beam specimens tested under low frictional support (Wille and Parra-Montesinos 2012). This was attributed to the increased internal moment due to the additional contribution of the horizontal reaction provided by the frictional force depending on the friction coefficient (Wille and ParraMontesinos 2012).

\subsection{Fiber and Rebar Pull-Out (Bond Strength)}

UHPC exhibited high bond strength to rebar and fibers owing to its dense micro- and macro-structures (Chan and Chu 2004; Holschemacher et al. 2004) (Table 9). The steel fibers pull-out behavior from UHPC is highly dependent on the fiber orientation and inclination with respect to the loading direction. A $30^{\circ}$ inclination with the loading direction resulted in higher pull-out load due to a snubbing effect and concrete matrix spalling (Lee et al. 2010). Moreover, hooked end or twisted fibers exhibited improved bond strength compared to that of straight fibers due to improved mechanical anchorage (Wille et al. 2012). The age of test specimens had minimum effect on the rebar-UHPC initial bond stiffness (Holschemacher et al. 2004). However, a significant effect of the specimen age was observed on the 
Table 8 Effect of steel fiber dosage and beam size on flexural capacity of UHPC.

\begin{tabular}{|c|c|c|c|c|}
\hline References & Fiber $(L / D)(\mathrm{mm} / \mathrm{mm})$ & Fiber content $(\%)$ & Specimen size $(\mathrm{mm})$ & Flexural strength $(\mathrm{MPa})$ \\
\hline \multirow[t]{2}{*}{ Collepardi et al. (1997) } & \multirow[t]{2}{*}{$13 / 0.18$} & \multirow[t]{2}{*}{2.5} & $150 \times 150 \times 600$ & 20.2 \\
\hline & & & $40 \times 40 \times 160$ & 48.3 \\
\hline \multirow[t]{4}{*}{ Herold and Muller (2004) } & \multirow[t]{4}{*}{$8 / 0.17$} & 0.0 & \multirow[t]{4}{*}{$40 \times 40 \times 160$} & 21.1 \\
\hline & & 0.5 & & 25.3 \\
\hline & & 2.5 & & 34.1 \\
\hline & & 4.0 & & 46.2 \\
\hline $\begin{array}{l}\text { Bornemann and Faber } \\
\qquad(2004)\end{array}$ & $9 / 0.15$ & 2.0 & $150 \times 150 \times 700$ & 22.0 \\
\hline \multirow[t]{3}{*}{ Guvensoy et al. (2004) } & \multirow[t]{3}{*}{$6 / 0.15$} & 5.0 & \multirow[t]{3}{*}{$70 \times 70 \times 280$} & 30.3 \\
\hline & & 5.5 & & 49.2 \\
\hline & & 6.0 & & 54.4 \\
\hline \multirow[t]{9}{*}{ Orgass and Klug (2004) } & \multirow[t]{9}{*}{$13 / 0.16$} & 0.0 & \multirow[t]{3}{*}{$150 \times 150 \times 700$} & 10.6 \\
\hline & & 1.0 & & 11.9 \\
\hline & & 2.0 & & 13.4 \\
\hline & & 0.0 & \multirow[t]{3}{*}{$100 \times 100 \times 500$} & 9.8 \\
\hline & & 1.0 & & 11.2 \\
\hline & & 2.0 & & 14.7 \\
\hline & & 0.0 & \multirow[t]{3}{*}{$40 \times 40 \times 160$} & 9.9 \\
\hline & & 1.0 & & 11.6 \\
\hline & & 2.0 & & 18.3 \\
\hline \multirow[t]{3}{*}{ Soutsos et al. (2005) } & \multirow[t]{3}{*}{$12 / 0.16$} & 0.0 & \multirow[t]{3}{*}{$40 \times 40 \times 160$} & 18.4 \\
\hline & & 1.5 & & 37.3 \\
\hline & & 2.0 & & 40.3 \\
\hline \multirow[t]{2}{*}{ Allena and Newtson (2010) } & \multirow[t]{2}{*}{$13 /-$} & 0.0 & \multirow[t]{2}{*}{$75 \times 100 \times 400$} & 10.9 \\
\hline & & 1.5 & & 18.3 \\
\hline \multirow{2}{*}{$\begin{array}{l}\text { Wille and Parra-Montesinos } \\
\text { (2012) }\end{array}$} & \multirow[t]{2}{*}{$13 / 0.20$} & \multirow[t]{2}{*}{1.5} & $152 \times 152 \times 508$ & 14.8 \\
\hline & & & $102 \times 102 \times 406$ & 15.8 \\
\hline \multirow[t]{4}{*}{ Magureanu et al. (2012) } & \multirow[t]{4}{*}{$25 / 0.40+6 / 0.17$} & 0.0 & \multirow[t]{2}{*}{$40 \times 40 \times 160$} & 13.9 \\
\hline & & 2.5 & & 34.0 \\
\hline & & 0.0 & \multirow[t]{2}{*}{$100 \times 100 \times 300$} & 9.4 \\
\hline & & 2.5 & & 23.0 \\
\hline \multirow[t]{6}{*}{ Kazemi and Lubell (2012) } & $13 / 0.2$ & 0.0 & $50 \times 50 \times 150$ & 22.1 \\
\hline & & 2.0 & & 29.1 \\
\hline & & 4.0 & & 48.0 \\
\hline & & 0.0 & $100 \times 100 \times 300$ & 15.0 \\
\hline & & 2.0 & & 23.1 \\
\hline & & 4.0 & & 38.4 \\
\hline
\end{tabular}


Table 8 continued

\begin{tabular}{|c|c|c|c|c|}
\hline References & Fiber $(L / D)(\mathrm{mm} / \mathrm{mm})$ & Fiber content $(\%)$ & Specimen size $(\mathrm{mm})$ & Flexural strength $(\mathrm{MPa})$ \\
\hline \multirow[t]{5}{*}{ Kreiger et al. (2012) } & \multirow[t]{5}{*}{$14 / 0.18$} & \multirow[t]{5}{*}{2.0} & $51 \times 51 \times 229$ & 18.4 \\
\hline & & & $51 \times 51 \times 343$ & 19.8 \\
\hline & & & $51 \times 51 \times 457$ & 17.5 \\
\hline & & & $51 \times 51 \times 699$ & 18.0 \\
\hline & & & $76 \times 76 \times 343$ & 19.0 \\
\hline \multirow[t]{6}{*}{ Shu-hua et al. (2012) } & \multirow[t]{6}{*}{$18 / 0.20$} & 0.0 & \multirow{3}{*}{$40 \times 40 \times 160$} & 26.9 \\
\hline & & 1.0 & & 27.6 \\
\hline & & 2.0 & & 29.2 \\
\hline & & 0.0 & \multirow[t]{3}{*}{$100 \times 100 \times 400$} & 17.7 \\
\hline & & 1.0 & & 18.9 \\
\hline & & 2.0 & & 20.0 \\
\hline \multirow[t]{6}{*}{ Nguyen et al. (2013) } & \multirow{6}{*}{$\begin{array}{c}(30 / 0.3 \text { twisted })+(13 / 0.2 \\
\text { smooth })\end{array}$} & $1.0+0.5$ & \multirow[t]{2}{*}{$50 \times 50 \times 150$} & 29.6 \\
\hline & & $1.0+1.0$ & & 38.9 \\
\hline & & $1.0+0.5$ & \multirow[t]{2}{*}{$100 \times 100 \times 300$} & 23.9 \\
\hline & & $1.0+1.0$ & & 29.1 \\
\hline & & $1.0+0.5$ & \multirow[t]{2}{*}{$150 \times 150 \times 450$} & 20.5 \\
\hline & & $1.0+1.0$ & & 26.9 \\
\hline
\end{tabular}

maximum bond stress depending on the UHPC mixture design and proportions (Holschemacher et al. 2004). The shape of the bond stress-slip curve is highly dependent on the loading rate. For instance, the smaller the loading rate $(0.001 \mathrm{~mm} / \mathrm{s})$, the steeper was the ascending slope (higher bond stiffness) and curve flattening becomes steadier in the descending branch of the bond stress-slip curve. However, higher loading rate (i.e. $0.1 \mathrm{~mm} / \mathrm{s}$ ) yielded higher bond stress and corresponding displacement (Holschemacher et al. 2004). Moreover, it was observed that the bond strength of rebar embedded in steel fiber-reinforced UHPC had less brittle pull-out failure and exhibited larger deformations compared to that of similar rebar embedded in UHPC without steel fibers (Maroliya 2012).

\subsection{Reinforcement Cover}

UHPC elements typically require smaller reinforcement cover due to the improved mechanical and durability properties. UHPC incorporating steel fibers exhibits higher tensile properties, thus preventing splitting cracks and concrete spalling (Holschemacher et al. 2004). Furthermore, the decreased permeability due to the very low porosity of UHPC mitigates the intrusion of aggressive species (e.g. chloride ions) into the hardened matrix and the subsequent attack on the steel reinforcement even when the reinforcement cover is relatively thin. Smaller reinforcement covers in UHPC members further reduce the cross-sectional dimensions leading towards economical construction.

\subsection{UHPC Under Dynamic and Impact Loading}

Very limited literature is available on the behavior of UHPC under dynamic effects such as earthquake or impact loading. Rebentrost and Wight (2008) reported that the application of UHPC reduced the earthquake design loads due to decreased overall structural weight, leading to more cost-effective construction. UHPC has also shown excellent performance against impact loading. Farnam et al. (2008) tested UHPC panels against an impact load of $8.5 \mathrm{~kg}$ and concluded that the member thickness, fiber type, fiber length and fiber dosage were important parameters responsible for impact resistance (Farnam et al. 2008). UHPC has the ability to dissipate higher energy under impact loads than that of NSC due to its high strength and ductility properties (Bindiganavile et al. 2002). Sun and Jiao (2011) reported 1.5 times increase in impact axial tensile strength of steel fiberreinforced UHPC specimens compared to that of NSC. Soe et al. (2013) studied the impact resistance of engineered cementitious composite (ECC) panels and observed higher impact resistance of hybrid fiber ECC compared to that of plain concrete.

Astarlioglu and Krauthammer (2014) studied the behavior of UHPC columns under blast loading using a single degree of freedom approach. UHPC columns exhibited around $30 \%$ smaller displacement compared to that of control NSC columns. Moreover, UHPC can resist four times higher impulsive loadings before failure compared to that of NSC (Astarlioglu and Krauthammer 2014). It was observed that shear is the governing behavior for UHPC under blast 
Table 9 Bond strength of steel fiber and rebar in UHPC.

\begin{tabular}{|c|c|c|c|c|c|}
\hline References & Reinforcement type & Diameter $(\mathrm{mm})$ & $\begin{array}{l}\text { Embedded length } \\
(\mathrm{mm})\end{array}$ & Curing regime & Bond strength (MPa) \\
\hline Behloul (1996) & \multirow[t]{2}{*}{$13 \mathrm{~mm}$ steel fiber } & 0.15 & - & - & 11.5 \\
\hline Chan and Chu (2004) & & 0.16 & 10 & $\begin{array}{c}85{ }^{\circ} \mathrm{C} \text { and } 90 \% \mathrm{RH} \\
\text { for } 3 \text { days }\end{array}$ & 5.5 \\
\hline \multirow[t]{3}{*}{ Lee et al. (2010) } & $13 \mathrm{~mm}$ steel fiber at $0^{\circ}$ & 0.20 & \multirow[t]{3}{*}{6.5} & \multirow{3}{*}{$\begin{array}{c}\text { Steam curing } 90^{\circ} \mathrm{C} \text { for } \\
2 \text { days }\end{array}$} & 6.8 \\
\hline & $\begin{array}{c}13 \mathrm{~mm} \text { steel fiber at } \\
15^{\circ}\end{array}$ & 0.20 & & & 10.8 \\
\hline & $\begin{array}{l}13 \mathrm{~mm} \text { steel fiber at } \\
30^{\circ}\end{array}$ & 0.20 & & & 12.7 \\
\hline \multirow{3}{*}{$\begin{array}{l}\text { Wille and Naaman } \\
\qquad(2012)\end{array}$} & $13 \mathrm{~mm}$ steel fiber & 0.20 & \multirow[t]{3}{*}{6.5} & \multirow{3}{*}{$\begin{array}{c}20{ }^{\circ} \mathrm{C} \text { (Laboratory } \\
\text { environment) }\end{array}$} & 10.4 \\
\hline & $\begin{array}{c}30 \mathrm{~mm} \text { steel fiber } \\
\text { twisted }\end{array}$ & 0.30 & & & 46.9 \\
\hline & $\begin{array}{c}30 \mathrm{~mm} \text { steel fiber } \\
\text { hooked }\end{array}$ & 0.30 & & & 42.2 \\
\hline \multirow[t]{4}{*}{ Park et al. (2014) } & $\begin{array}{c}30 \mathrm{~mm} \text { smooth steel } \\
\text { fiber }\end{array}$ & 0.30 & \multirow[t]{3}{*}{15} & \multirow[t]{4}{*}{$\begin{array}{c}\text { Water curing at } 90^{\circ} \mathrm{C} \\
\text { for } 3 \text { days }\end{array}$} & 9.9 \\
\hline & $\begin{array}{c}30 \mathrm{~mm} \text { hooked steel } \\
\text { fiber }\end{array}$ & 0.37 & & & 11.7 \\
\hline & $\begin{array}{c}62 \mathrm{~mm} \text { hooked steel } \\
\text { fiber }\end{array}$ & 0.77 & & & 11.4 \\
\hline & $\begin{array}{c}30 \mathrm{~mm} \text { twisted steel } \\
\text { fiber }\end{array}$ & 0.30 & 6 & & 32.0 \\
\hline Collepardi et al. (1997) & Deformed rebar & 20 & - & Standard & 28.4 \\
\hline Cheyrezy et al. (1998) & Prestressing strand & 13 & - & Standard & 35.0 \\
\hline Cheyrezy et al. (1998) & Prestressing wire & 5 & - & Standard & 10.0 \\
\hline $\begin{array}{l}\text { Reineck and Greiner } \\
\qquad(2004)\end{array}$ & Deformed rebar & 4 & 8 & - & 46.0 \\
\hline \multirow{4}{*}{$\begin{array}{l}\text { Holschemacher et al. } \\
\qquad(2004)\end{array}$} & Deformed rebar & 10 & \multirow[t]{4}{*}{15} & Under water, 3 days & 34.0 \\
\hline & Deformed rebar & 10 & & Under water, 7 days & 47.0 \\
\hline & Deformed rebar & 10 & & Under water, 28 days & 68.0 \\
\hline & Deformed rebar & 10 & & Under water, 56 days & 70.0 \\
\hline $\begin{array}{l}\text { Holshemacher et al. } \\
\qquad(2005)\end{array}$ & Deformed rebar & 10 & - & - & 56.0 \\
\hline Lee et al. (2005) & Epoxy coated rebar & 10 & - & - & 12.7 \\
\hline Tuchlinski et al. (2006) & Prestressing strand & 13 & - & - & 15.0 \\
\hline \multirow[t]{2}{*}{ Maroliya (2012) } & Deformed rebar & 8 & \multirow[t]{2}{*}{75} & \multirow[t]{2}{*}{ Hot water curing } & 4.8 \\
\hline & Deformed rebar & 8 & & & 7.5 \\
\hline
\end{tabular}

loading (Millard et al. 2010). Barnett et al. (2010) tested UHPC panels of $3.50 \times 1.30 \times 0.10 \mathrm{~m}$ in size under blast loading using $100 \mathrm{~kg}$ TNT placed at different distances $(7,9$ and $12 \mathrm{~m}$ ). UHPC panels with conventional rebar reinforcement were able to sustain blast pressure of around $2500 \mathrm{kPa}$; UHPC panels incorporating steel fibers broke into two pieces at a blasting pressure of $500 \mathrm{kPa}$ (Schleyer et al. 2011). These experimental results correlated well with numerical findings (Mao et al. 2014). Mao et al. (2015) studied the effect of blast loading on UHPC slabs incorporating different types and dosages of steel fibers. It was observed that an increase in fiber dosage improved the blast resistance of UHPC slabs. It was also observed that UHPC mixtures incorporating long steel fibers exhibited enhanced performance under impact loading compared to that incorporating short fibers (Yu et al. 2014). Aoude et al. (2015) tested UHPC columns under simulated blast loading using a shock tube testing facility. It was observed that the concrete 
type, fiber type and dosage, longitudinal reinforcement ratio and spacing between transverse reinforcement were the important parameters that effect the failure pattern of UHPC columns subjected to blast loading (Aoude et al. 2015).

UHPC application is desirable in military structures where impact resistance due to blast loading is of concern. UHPC structural elements showed improved behavior against explosive load compared to that of HPC and NSC (Millon et al. 2012; Ngo et al. 2007). The development of multiple micro-cracks (crack width of about $0.50 \mathrm{~mm}(0.02$ in)) without fragmentation or spalling was observed in UHPC members, leading to decreased global structural damage. The improved cracking behavior was attributed to the addition of high strength steel fibers, which increased energy absorption capacity and improved ductility (Millon et al. 2012).

\subsection{Fatigue Behavior}

A large scatter exists in fatigue test results of UHPC (Table 10). This was attributed to variation in material strength, applied stress level, distribution of fibers, number of fibers at critical cross-sections and test specimen type and size (Table 10) (Lappa et al. 2004; Grunberg and Ertel 2012). For instance, UHPC specimens showed no significant sign of failure after $10^{6}$ load cycles (Bornemann and Faber 2004). UHPC fatigue results demonstrated that deformations increased rapidly during the initial cycling (up to $5 \%$ of the fatigue life) and then grew constantly at the intermediate stage (5-95\% of the fatigue life). Before the failure point (95-100\% of the fatigue life), deformation increased rapidly again (Lappa et al. 2004; Grunberg et al. 2008). Under fatigue loading, fiber-reinforced UHPC specimens exhibited large variation in local deformations, indicating the ability of UHPC to redistribute stresses and strains, leading to enhanced fatigue behavior (Makita and Bruhwiler 2013). However, an increase in material global strain up to $1.6 \%$ (strain hardening stage) decreased the deformation modulus from 39 to $10 \mathrm{GPa}$ due to cracking of the UHPC matrix and fiber pull-out (Makita and Bruhwiler 2013). Moreover, Lohaus and Elsmeier (2012), confirmed that UHPC with or without steel fibers exhibited fatigue life considerably higher than predictions of the CEBFIP Model Code-90 (1993). The UHPC fatigue life (number of cycles to failure) decreased with increased load or stress level (Table 10). The slopes of the loading and unloading curves for UHPC specimens during cyclic loads were nearly identical, indicating an insignificant degradation in stiffness properties (Guvensoy et al. 2004). However, a decreasing trend in residual stresses was observed after achieving the peak stress (Guvensoy et al. 2004). The fatigue fracture surfaces of UHPC incorporating fibers exhibited matrix spalling and fiber abrasion due to snubbing, fretting and grinding effects (Makita amd Bruhwiler 2013).

\section{Durability Properties}

\subsection{Porosity and Permeability}

UHPC exhibits high durability properties due to a substantial decrease in the number and size of pores (Heinz and
Ludwig 2004; Herold and Muller 2004). The average pore size in UHPC was found to be less than $5 \mathrm{~nm}\left(2 \times 10^{-7}\right.$ in $)$ and the pore volume ranges from 1 to $2 \%$ of the total volume (Vernet 2004; Heinz and Ludwig 2004; Teichmann and Schmidt 2004; Herold and Muller 2004; Dowd and Dauriac 1996; Roux et al. 1996). It was observed that the total porosity is mainly dependent on the heat treatment and $\mathrm{w} / \mathrm{b}$ (Table 11). For instance, the total porosity decreased from 8.4 to $1.5 \%$ due to UHPC heat treatment (Cwirzen 2007; Herold and Muller 2004; Cheyrezy et al. 1995). Furthermore, the application of pressure also reduced the overall porosity by removing the entrapped air and additional water (Richard and Cheyrezy 1995; Bonneau et al. 1997). For instance, Roux et al. (1996) observed $50 \%$ reduction in porosity upon the application of pressure during the initial setting time.

UHPC shows very low water absorption capacity, which is approximately 10 and 60 times lesser than that of HPC and NSC, respectively (Schmidt and Fehling 2005; Ghafari et al. 2012; Roux et al. 1996; Pierard and Cauberg 2009). The water permeability coefficient of UHPC was reported to be about 0.0005 , which is very low compared to that of the NSC (around 0.0015) (Wang et al. 2015). The water sorptivity coefficient of UHPC was found to be less than $0.044 \mathrm{~kg} / \mathrm{m}^{2} / \mathrm{h}^{0.5}$ (Table 12 ), which is approximately 15 times lower compared to that of typical HPC (Ghafari et al. 2012). Likewise, UHPC showed very low permeability to oxygen as compared to that of NSC and HPC. For instance, the UHPC permeability to oxygen is less than $1 \times 10^{-19} \mathrm{~m}^{2}$ $\left(1 \times 10^{-18} \mathrm{ft}^{2}\right)$, which is around 10 and 100 times lesser than that of HPC and NSC, respectively (Vernet 2004; Wang et al. 2014). Furthermore, Roux et al. (1996) found no penetration of carbon dioxide $\left(\mathrm{CO}_{2}\right)$ into UHPC specimens after 90 days of exposure. However, at later ages, some $\mathrm{CO}_{2}$ penetration was measurable. For instance, a carbonation depth of $0.5 \mathrm{~mm}$ (0.020 in) was observed after 6 months of $\mathrm{CO}_{2}$ exposure (Schmidt et al. 2003; Perry and Zakariasen 2004). In another study conducted by Schmidt and Fehling (2005), a carbonation depth of $1.5 \mathrm{~mm}(0.060 \mathrm{in})$ after 3 years was found for UHPC, which is approximately 2.5 and 4.5 times less than that in HPC and NSC, respectively.

\subsection{Chloride Ions Penetration Properties}

The maximum chloride ions content and penetration depth in UHPC specimens reported by various researchers are listed in Tables 13 and 14. It can be observed that the chloride ions penetration is highly dependent on the exposure solution and duration, $\mathrm{w} / \mathrm{b}$ and curing regimes (Thomas et al. 2012; Scheydt and Muller 2012). Furthermore, accelerated tests were conducted by applying pressure and voltage on UHPC specimens in order to evaluate the forced chloride penetration depth into UHPC specimens. For instance, Gao et al. (2006) reported penetration depth of $2.7 \mathrm{~mm}(0.11 \mathrm{in})$ with hydraulic pressure of $1.6 \mathrm{MPa}(230$ psi) after $128 \mathrm{~h}$. The chloride diffusion coefficient (Table 15$)$ for UHPC $\left(2 \times 10^{-14} \mathrm{~m}^{2} / \mathrm{s}\right)$ is significantly lower than that of HPC (around $6 \times 10^{-13} \mathrm{~m}^{2} / \mathrm{s}$ ) and NSC (around $1 \times 10^{-12} \mathrm{~m}^{2} / \mathrm{s}$ ) (Roux et al. 1996). The chloride ions 


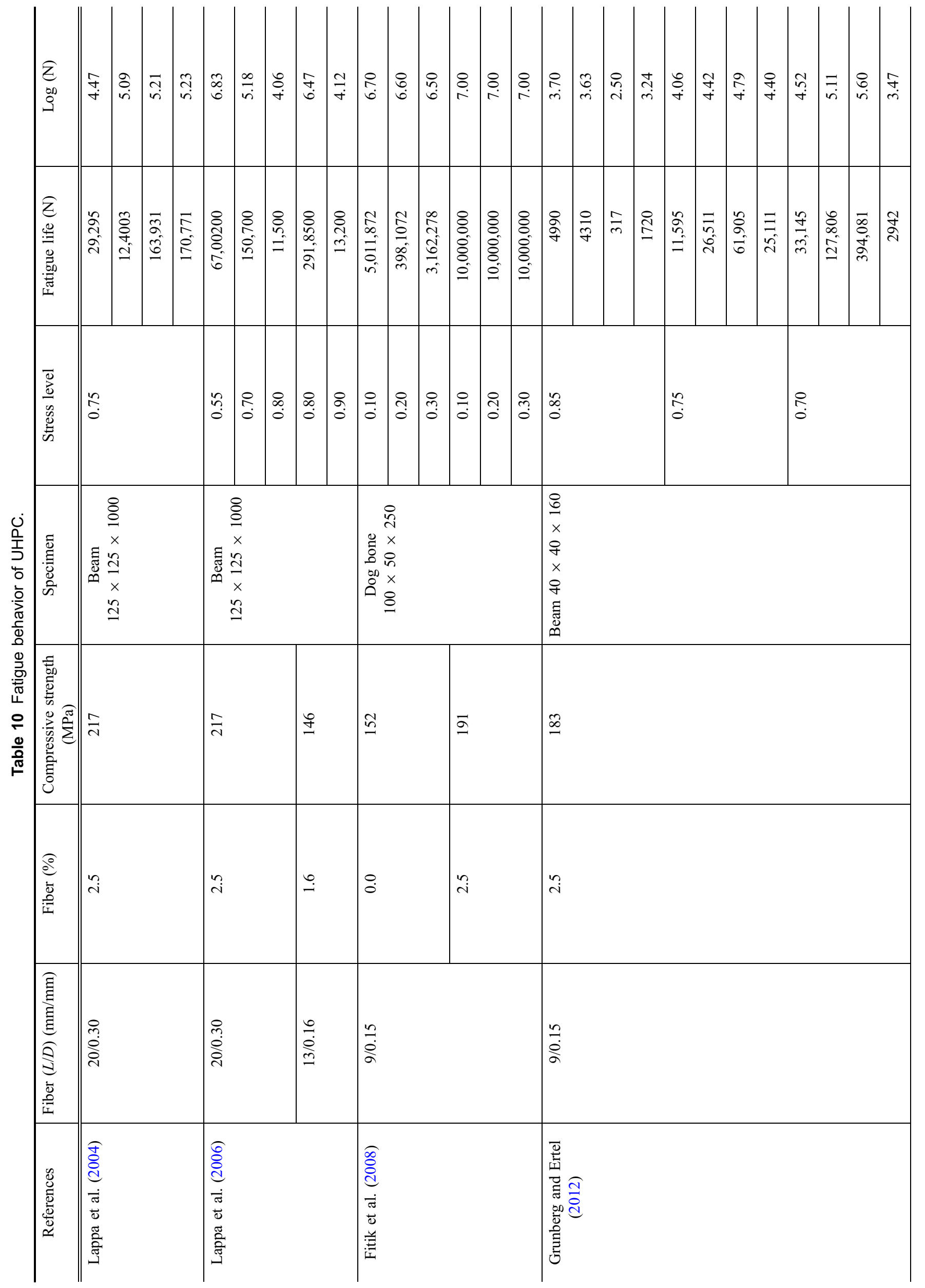




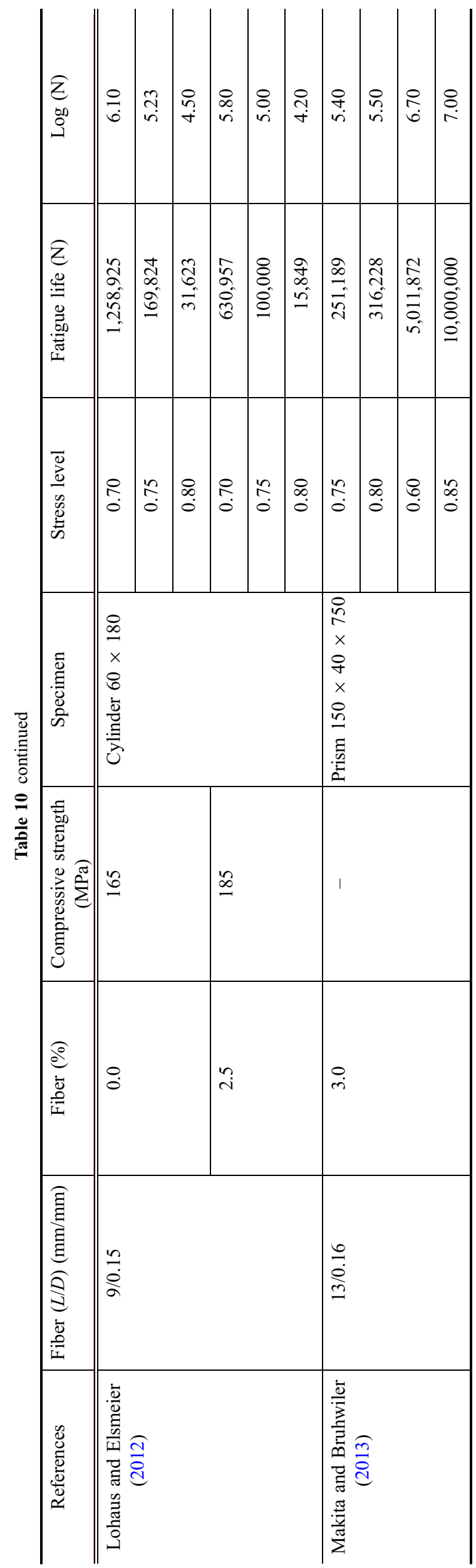

penetration can also be estimated in terms of the number of coulombs (electric charge) passed through the specimens using the rapid chloride ion penetrability test (ASTM C1202 2010). It was observed that the addition of steel fibers in UHPC did not cause any electrical short circuiting during the rapid chloride ion penetrability test due to their shorter length and randomly discontinuous distribution (Graybeal 2006; Ahlborn et al. 2008). It was also found that the total charges passed through thermally treated UHPC specimens (35 mm (1.4 in) thick) was 22 Coulombs, which is very low compared to that of HPC (e.g. 216 Coulombs) and NSC (e.g. 1736 Coulombs) (Schmidt et al. 2003). It was argued that thermal treatment is a key factor controlling charges passed through UHPC specimens (Table 16).

\subsection{Corrosion Rate of Rebars}

The corrosion rate for reinforcing rebar in UHPC was found to be $0.01 \mu \mathrm{m} /$ year $\left(4 \times 10^{-7} \mathrm{in} /\right.$ year $)$, which is much lower than the limiting value of $1 \mu \mathrm{m} /$ year $\left(4 \times 10^{-5} \mathrm{in} /\right.$ year), showing no significant potential for the corrosion risk provided that the quality of UHPC is assured (Roux et al. 1996). Furthermore, UHPC mixtures incorporating nanosilica showed enhanced corrosion resistance of steel rebar (Ghafari et al. 2015).

\subsection{Freeze-Thaw Damage and Surface Scaling}

The reduced permeability and porosity of UHPC enables better resistance to freezing-thawing cycles (Graybeal 2006; Bonneau et al. 2000) (Table 17). For example, no freezethaw degradation was observed for UHPC specimens after 800 of freezing-thawing cycles, which was attributed to less interconnected pores (Bonneau et al. 1997; Juanhong et al. 2009). The study conducted by Vernet (2004) at the Weathering Exposure Station, Treat Island, USA found no considerable deterioration on UHPC after 500 freezingthawing cycles along with 4500 wetting-drying cycles. Furthermore, it was observed that the addition of steel fibers appeared to decrease the internal material degradation due to freeze-thaw cycling (Cwirzen et al. 2008). No significant length and weight change in UHPC specimens were reported after 300 freeze-thaw cycles (Juanhong et al. 2009; Shaheen and Shrive 2006). Moreover, UHPC exhibited $8-60 \mathrm{~g} / \mathrm{m}^{2}$ (3.03-22.78 oz. $\left./ \mathrm{ft}^{2}\right)$ of surface scaling due to de-icing salts after 50 cycles of freezing-thawing (Bonneau et al. 1997; Perry and Zakariasen 2004). This variation in observed surface scaling values was attributed to the different testing techniques adopted. Studies concluded that the mass loss due to surface scaling in UHPC is well below the limiting values $\left(1000-1500 \mathrm{~g} / \mathrm{m}^{2}\left(380-570 \mathrm{oz} . / \mathrm{ft}^{2}\right)\right.$ ) (Schmidt and Fehling 2005; Vernet 2004; Cwirzen 2007; Pierard and Cauberg 2009).

\subsection{Expansion Due to Alkali-Silica Reactivity}

Very limited research was conducted on the alkali-silica reaction (ASR) in UHPC. Graybeal (2006) performed ASR testing on small UHPC prisms $25 \times 25 \times 280 \mathrm{~mm}$ $(3.97 \times 3.97 \times 11.02$ in $)$ by submerging them in a sodium hydroxide solution for $2-4$ weeks at $80{ }^{\circ} \mathrm{C}\left(176^{\circ} \mathrm{F}\right)$. 
Table 11 Effect of w/b and curing regime on UHPC porosity.

\begin{tabular}{|c|c|c|c|c|}
\hline References & UHPC type & $\mathrm{w} / \mathrm{b}$ & Curing regimes & Total porosity $(\%)$ \\
\hline \multirow[t]{6}{*}{ Heinz and Ludwig (2004) } & \multirow[t]{6}{*}{ Fiber cocktail } & \multirow[t]{6}{*}{$0.22 *$} & $20{ }^{\circ} \mathrm{C}$ and $93 \% \mathrm{RH}$ & 8.2 \\
\hline & & & $65^{\circ} \mathrm{C}$ and $93 \% \mathrm{RH}$ & 5.3 \\
\hline & & & $90{ }^{\circ} \mathrm{C}$ and $93 \% \mathrm{RH}$ & 4.2 \\
\hline & & & $105{ }^{\circ} \mathrm{C}$ and $93 \% \mathrm{RH}$ & 4.0 \\
\hline & & & $120{ }^{\circ} \mathrm{C}$ and $93 \% \mathrm{RH}$ & 3.5 \\
\hline & & & $180{ }^{\circ} \mathrm{C}$ and $93 \% \mathrm{RH}$ & 2.9 \\
\hline \multirow[t]{2}{*}{ Herold and Muller (2004) } & \multirow[t]{2}{*}{ With steel fiber } & \multirow[t]{2}{*}{0.16} & $20{ }^{\circ} \mathrm{C}$ & 10.5 \\
\hline & & & $90{ }^{\circ} \mathrm{C}$ for 2 days & 6.4 \\
\hline \multirow[t]{2}{*}{ Cwirzen (2007) } & \multirow[t]{2}{*}{ No steel fibers } & \multirow[t]{2}{*}{0.17} & Storage at $95 \% \mathrm{RH}$ & 5.8 \\
\hline & & & $90{ }^{\circ} \mathrm{C}$ for 4 days & 1.1 \\
\hline \multirow[t]{3}{*}{ Scheydt and Muller (2012) } & \multirow[t]{2}{*}{ With steel fibers } & \multirow[t]{3}{*}{0.21} & Water cured at $28^{\circ} \mathrm{C}$ & 8.9 \\
\hline & & & $90{ }^{\circ} \mathrm{C}$ for 3 days & 5.4 \\
\hline & No steel fibers & & Water cured at $28^{\circ} \mathrm{C}$ & 10.9 \\
\hline
\end{tabular}

$R H$ relative humidity; $0.22 *=0.22 \mathrm{w} / \mathrm{c}$.

Average ASR expansion values of 0.012 and $0.002 \%$ at 28 days were observed for untreated and thermally treated specimens, respectively, indicating the significant effect of thermal curing on UHPC ASR expansion. Another study conducted by Moser et al. (2009) showed a maximum ASR expansion of $0.02 \%$ for both undamaged and pre-damaged UHPC specimens after 600 days, which is lower than the threshold limit of $0.04 \%$ (Moser et al. 2009).

\subsection{UHPC Under Fire/Elevated Temperature}

UHPC structures can be more vulnerable to fire and elevated temperatures due to its reduced porosity, which hinders the release of vapor pressure, leading to physical damage (Way and Wille 2012). However, the use of polypropylene (PP) fibers can mitigate this issue. Various studies (Schmidt et al. 2004; Heinz et al. 2004) showed that the addition of $0.6 \%$ by mixture volume of PP fibers improved the fire resistant properties (prevented spalling) of UHPC since melting of the PP fibers at high temperature creates space to release the build-up of pressure. However, cracks $[0.3-0.5 \mathrm{~mm}(0.012-0.020 \mathrm{in})]$ were observed at the specimen's surface. Furthermore, disintegration of UHPC mechanical properties was observed due to dehydration of calcium silicate hydrate products, chemical decomposition of UHPC materials and thermal expansive damage (Way and Wille 2012; Pimienta et al. 2012). It was observed that UHPC with $0.6 \%$ PP fibers by volume mixture achieved weight loss of less than $9 \%$ at $1000{ }^{\circ} \mathrm{C}\left(1832{ }^{\circ} \mathrm{F}\right)(\mathrm{Heinz}$ et al. 2004).

Moreover, Tai et al. (2011) reported an increase in compressive strength of UHPC specimens heated up to $300{ }^{\circ} \mathrm{C}$; however, a decreasing trend in compressive strength was observed beyond $300{ }^{\circ} \mathrm{C}$. A declining trend in mechanical properties of UHPC at elevated temperature was mainly due to the weakening of internal microstructure ( $\mathrm{Li}$ and $\mathrm{Liu}$ 2016). An improved behavior at elevated temperature was observed with the addition of steel fibers in UHPC specimens (Tai et al. 2011; Li and Liu 2016; Zheng et al. 2012).

\section{Cost Estimation and Sustainability of UHPC}

Generally, the initial material cost of UHPC is higher than that of NSC and HSC due to its very high cement content and steel fiber addition. Table 18 compares the cost of UHPC per unit volume in Europe and North America. In North America, the cost of UHPC is higher than that in Europe due to its limited use. The application of UHPC can result in more sustainable construction due to possibly better economic, social and environmental impacts. The overall cost of structures is directly linked with the crosssectional dimensions of structural elements. The use of UHPC structural members assists in reducing the crosssectional dimensions (Hajek and Fiala 2008) thereby freeing additional useful space in buildings. The material cost can also be reduced compared to that of a larger crosssection NSC member, even though the cement content required in UHPC is higher. Moreover, the quantity of fine aggregates can be reduced to $30 \%$, while no coarse aggregate is used in UHPC (Walraven 2008). Racky (2004) concluded that approximately $56 \%$ reduction in materials costs can be achieved by utilizing UHPC rather than NSC. The high-strength properties of UHPC allow the design of slender structures, leading to reduction in self-weight of the structure due to less use of materials. This can also result in decreasing the demolition waste, leading to reduced transportation demand and consequently, lesser effects on the 
Table 12 UHPC water sorptivity coefficient.

\begin{tabular}{c|c|c|c|c}
\hline References & $\mathrm{w} / \mathrm{b}$ & Curing conditions & Fiber & $\begin{array}{c}\text { Sorptivity coefficient }(\mathrm{kg} / \\
\mathrm{m}^{2} / \mathrm{h}\end{array}$ \\
\hline \hline Roux et al. (1996) & 0.14 & $20{ }^{\circ} \mathrm{C}$ water cured & $2 \%$ & 0.0100 \\
\cline { 2 - 3 } & & $20{ }^{\circ} \mathrm{C}$ water cured & & 0.0052 \\
\hline Franke et al. (2008) & 0.17 & $90{ }^{\circ} \mathrm{C}$ for 2 days & No fiber & 0.0330 \\
\cline { 2 - 2 } & 0.19 & & & 0.0440 \\
\hline
\end{tabular}

Table 13 Maximum chloride ions penetration into UHPC.

\begin{tabular}{c|c|c|c|c|c}
\hline References & Curing regimes & $\mathrm{w} / \mathrm{b}$ & Exposure solution & $\begin{array}{c}\text { Exposure period } \\
\text { Maximum chloride } \\
\text { contents }\end{array}$ \\
\hline \hline Roux et al. (1996) & $\begin{array}{c}20{ }^{\circ} \mathrm{C} \text { water cured } \\
(60 \mathrm{MPa} \text { pressure } \\
\text { applied during setting } \\
\text { time) }\end{array}$ & 0.14 & $0.5 \mathrm{M} \mathrm{NaCl}$ & - & $\begin{array}{c}0.03 \% \text { of concrete } \\
\text { mass }\end{array}$ \\
\hline $\begin{array}{c}\text { Scheydt and Muller } \\
(2012)\end{array}$ & Water cured & 0.21 & $3 \% \mathrm{NaCl}$ & 16 months & $\begin{array}{c}1.4 \% \text { by mass of } \\
\text { binder }\end{array}$ \\
\hline $\begin{array}{c}\text { Thomas et al. (2012) } \\
20{ }^{\circ} \mathrm{C} \text { for } 2 \text { days and } \\
90{ }^{\circ} \mathrm{C} \text { for another } \\
2 \text { days }\end{array}$ & 0.12 & $\begin{array}{c}\text { Marine environment at } \\
\text { Treat Island }\end{array}$ & 5 years & $\begin{array}{c}0.21 \% \text { of concrete } \\
\text { mass }\end{array}$ \\
\hline
\end{tabular}

Table 14 Chloride ions penetration depth into UHPC specimens for various salt exposures.

\begin{tabular}{c|c|c|c|c|c}
\hline References & Curing regimes & $\mathrm{W} / \mathrm{b}$ & Exposure solution & $\begin{array}{c}\text { Exposure period } \\
\text { Chloride penetration } \\
\text { depth }\end{array}$ \\
\hline \hline Graybeal (2006) & $\begin{array}{c}\text { Laboratory } \\
\text { environment }\end{array}$ & 0.12 & $3 \% \mathrm{NaCl}$ & 3 months & $4-6 \mathrm{~mm}$ \\
\hline \begin{tabular}{c} 
Scheydt et al. (2008) \\
\hline $\begin{array}{c}\text { Pierard and Cauberg } \\
(2009)\end{array}$
\end{tabular} & $20{ }^{\circ} \mathrm{C}$ for 3 days and $95 \% \mathrm{RH}$ & 0.18 & $3 \% \mathrm{NaCl}$ & 4 months & $2-3 \mathrm{~mm}$ \\
\hline \begin{tabular}{c} 
Thomas et al. (2012) \\
\hline $\begin{array}{c}\text { Scheydt and Muller } \\
(2012)\end{array}$
\end{tabular} & $90{ }^{\circ} \mathrm{C}$ for 2 days for 3 days & 0.12 & $\begin{array}{c}\text { Marine environment at } \\
\text { Treat Island }\end{array}$ & 5 years & $6-10 \mathrm{~mm}$ \\
\hline Pierard et al. (2012) & $20{ }^{\circ} \mathrm{C}$ for 90 days & 0.21 & $3 \% \mathrm{NaCl}$ & 16 months & $4-6 \mathrm{~mm}$ \\
\hline
\end{tabular}

Table 15 UHPC chloride ions diffusion coefficient for various curing exposures and w/b.

\begin{tabular}{c|c|c|c|c|c}
\hline References & Curing regimes & w/b & Exposure solution & $\begin{array}{c}\text { Exposure period } \\
\text { Diffusion coefficient } \\
\left(\times 10^{-13}\right)\end{array}$ & 0.20 \\
\hline \hline Roux et al. (1996) & $\begin{array}{c}20{ }^{\circ} \mathrm{C} \text { water cured and } \\
\text { pressure application }\end{array}$ & 0.14 & $0.5 \mathrm{M} \mathrm{NaCl}$ & - & 4.00 \\
\hline $\begin{array}{c}\text { Pierard and Cauberg } \\
(2009)\end{array}$ & $20{ }^{\circ} \mathrm{C}$ and $95 \% \mathrm{RH}$ & 0.18 & $16 \% \mathrm{NaCl}$ & - & 4.00 \\
\hline $\begin{array}{c}\text { Juanhong et al. (2009) } \\
90{ }^{\circ} \mathrm{C} \text { steam for } 1 \text { day }\end{array}$ & 0.15 & $10 \% \mathrm{NaCl}$ & $16 \% \mathrm{NaCl}$ & 1.30 \\
\hline $\begin{array}{c}\text { Scheydt and Muller } \\
(2012)\end{array}$ & $90{ }^{\circ} \mathrm{C}$ for 3 days & 0.21 & $16 \% \mathrm{NaCl}$ & 90 days & 2.30 \\
\hline $\begin{array}{c}\text { Pierard et al. (2012) } \\
\text { Thomas et al. (2012) }\end{array}$ & $90{ }^{\circ} \mathrm{C}$ for 90 days & 0.21 & Marine environment at \\
Treat Island & 5 years & 1.30 \\
\hline
\end{tabular}


Table 16 Number of coulombs passed through UHPC specimens.

\begin{tabular}{|c|c|c|c|}
\hline References & Curing regimes & $\mathrm{w} / \mathrm{b}$ or $\mathrm{w} / \mathrm{c}^{*}$ & Coulombs \\
\hline Bonneau et al. (1997) & - & - & 10 \\
\hline \multirow[t]{2}{*}{ Graybeal (2006) } & $90{ }^{\circ} \mathrm{C}$ for 2 days & \multirow[t]{2}{*}{0.12} & 18 \\
\hline & Laboratory environment & & 360 \\
\hline \multirow[t]{2}{*}{ Ahlborn et al. (2008) } & Air cured & \multirow[t]{2}{*}{$0.20^{*}$} & 75 \\
\hline & $90{ }^{\circ} \mathrm{C}$ and $100 \% \mathrm{RH}$ for 2 days & & 15 \\
\hline Scheydt and Muller (2012) & $90{ }^{\circ} \mathrm{C}$ for 3 days & 0.21 & 19 \\
\hline
\end{tabular}

* indicates the water-cement ratio $(\mathrm{w} / \mathrm{c})$

Table 17 UHPC freeze-thaw properties.

\begin{tabular}{|c|c|c|c|c|c|}
\hline References & $\mathrm{w} / \mathrm{b}$ or $\mathrm{w} / \mathrm{c}^{*}$ & Steel fibers & Curing regimes & Freeze-thaw cycles & $\begin{array}{l}\text { Relative dynamic } \\
\text { modulus (\%) }\end{array}$ \\
\hline \multirow{2}{*}{$\begin{array}{l}\text { Shaheen and shrive } \\
\qquad(2006)\end{array}$} & \multirow[t]{2}{*}{$0.13 *$} & $0 \%$ & \multirow[t]{2}{*}{$150{ }^{\circ} \mathrm{C}$} & \multirow[t]{2}{*}{300} & 101.00 \\
\hline & & $1.5 \%$ & & & 101.60 \\
\hline \multirow[t]{2}{*}{ Ahlborn et al. (2008) } & \multirow[t]{2}{*}{$0.20 *$} & \multirow[t]{2}{*}{$6 \%$} & Air & 300 & 101.57 \\
\hline & & & $\begin{array}{c}90^{\circ} \mathrm{C} \text { and } 100 \% \mathrm{RH} \\
\text { for } 2 \text { days }\end{array}$ & 300 & 100.29 \\
\hline Juanhong et al. (2009) & $0.21^{*}$ & $2 \%$ & $90^{\circ} \mathrm{C}$ steam for 1 day & 1500 & 101.00 \\
\hline \multirow[t]{4}{*}{$\begin{array}{c}\text { Magureanu et al. } \\
\text { (2012) }\end{array}$} & \multirow[t]{4}{*}{0.12} & \multirow[t]{2}{*}{$0 \%$} & $\mid \begin{array}{c}90{ }^{\circ} \mathrm{C} \text { and } 80 \text { to } 90 \% \\
\mathrm{RH} \text { for } 5 \text { days }\end{array}$ & 1095 & 100.78 \\
\hline & & & $\begin{array}{c}20^{\circ} \mathrm{C} \text { and } 80 \text { to } 90 \% \\
\mathrm{RH} \text { for } 5 \text { days }\end{array}$ & 1095 & 100.40 \\
\hline & & \multirow[t]{2}{*}{$2.5 \%$} & $\begin{array}{c}90{ }^{\circ} \mathrm{C} \text { and } 80 \text { to } 90 \% \\
\mathrm{RH} \text { for } 5 \text { days }\end{array}$ & 1095 & 100.40 \\
\hline & & & $\begin{array}{c}20^{\circ} \mathrm{C} \text { and } 80 \text { to } 90 \% \\
\mathrm{RH} \text { for } 5 \text { days }\end{array}$ & 1095 & 100.60 \\
\hline
\end{tabular}

* indicates the water-cement ratio $(\mathrm{w} / \mathrm{c})$

environment (Hajek and Fiala 2008). Furthermore, the utilization of by-products such as fly ash/silica fume instead of cement makes UHPC more sustainable (Aitcin 2000). UHPC members require less maintenance cost due to their improved durability characteristics; and hence their life-cycle cost can be reduced while yielding much longer service life (Racky 2004; Blais and Couture 2000). Likewise, neighboring communities would not be disturbed by the routines of maintenance or/and replacement of the facility, leading to positive social effect. Clearly, not all the cement available in UHPC is hydrated. Thus, recycling of UHPC can be used more effectively because the un-hydrated cement is available for further reactions (Aitcin 2000). The favorable environmental impacts of UHPC also include lower effect on the ozone layer, less potential to harm the environment and less greenhouse gas emissions. A study reported by Schmidt and Teichmann (2007) concluded that the utilization of UHPC results in $50 \%$ energy reduction compared to that of NSC. In short, UHPC can be a sustainable material due to its improved durability, ecological factors, economical benefits and its recycle-ability in various applications.

\section{Current Challenges for Implementation of UHPC}

Although UHPC is being utilized in several applications around the world, it still faces some challenges for wider implementation, especially in North America. The benefits of this innovative material are still not well known. The major challenges that need to be addressed in order to provide a higher level of comfort to stakeholders, designers, contractors and manufacturers for implementing UHPC successfully in the field include:

1. Developing a rational and accurate method for the optimization of UHPC constituents and mixture design (rather than relying on trial mixes) to ensure successful development of UHPC and its wider implementation in the field.

2. Due to the very low w/b of UHPC, high energy mixers are required for properly mixing its constituents. Furthermore, a number of modifications in precast site mixers are required for the successful production of UHPC precast elements. 
Table 18 UHPC cost estimation.

\begin{tabular}{c|c|c|c}
\hline \multirow{2}{*}{ References } & \multicolumn{2}{|c|}{ Estimated cost } & \multirow{2}{*}{ Regions } \\
\cline { 2 - 3 } & $\$ / \mathrm{m}^{3}$ & 1070 & \multirow{2}{*}{ Europe } \\
\hline \hline Bonneau et al. (1996) & 1400 & 520 & \\
\hline Blais and Couture (2000) & 750 & 760 & \\
\hline Aitcin (2000) & 1000 & 2000 & North America \\
\hline Voort et al. (2008) & 2620 & & \\
\hline
\end{tabular}

3. The flexural properties of UHPC are predominantly influenced by the orientation of fibers. Therefore, developing a reliable method allowing the effective distribution of fibers in its matrix with desired orientation is required, especially for casting slender elements.

4. Shrinkage strains in UHPC mixtures are higher than that in normal concrete. Therefore, special admixtures or preventive measures are required for mitigating issues related to dimensional stability particularly in full-scale structures.

5. The high strength and durability properties of UHPC are highly dependent on thermal treatment. Therefore, special arrangements for thermal curing for on-site construction and at precast facilities need to be explored.

6. Widely accepted, simple and rational design provisions need to be developed for UHPC (reinforced and nonreinforced) in order to provide confidence to the design engineer for effectively utilizing the high strength and other unique properties of UHPC.

\section{Summary and Conclusions}

An extensive literature review was conducted in this study on the distinctive features of UHPC. The unique properties of UHPC have several advantages over normal-strength concrete (NSC) owing to its material ingredients and composition. The key factor in producing UHPC is to improve the micro and macro properties of its mixture constituents to ensure mechanical homogeneity and denser particle packing. UHPC yields high compressive strength (i.e. $>150 \mathrm{MPa}$ (22 ksi)) due to its improved internal micro- and macrostructure, leading to denser concrete. The application of thermal curing further densifies UHPC, which results in higher compressive strength properties. The typical heat treatment applied for UHPC is $90-400{ }^{\circ} \mathrm{C}\left(194-752{ }^{\circ} \mathrm{F}\right)$ for 2-6 days. The specimen size significantly affects the measured compressive strength of UHPC. Smaller size specimens can be used if the test machine capacity is limited. Furthermore, it was observed that the loading rate did not significantly affect the measured compressive strength of UHPC. The compressive stress-strain response of UHPC shows a linear elastic behavior up to $80-90 \%$ of the maximum stress value.

UHPC exhibits high flexural strength properties (i.e. up to $48 \mathrm{MPa}(7.0 \mathrm{ksi})$ ) depending on its mixture design and curing regime. It was reported that horizontally cast beam specimens achieved nearly five times higher flexural strength compared to that of vertically cast beam specimens due to improved fiber orientation. Furthermore, the flexural strength of UHPC is dependent on the pouring method of concrete into molds. For instance, pouring concrete from one end of the mold increased the flexural strength compared to that of the same concrete poured from different places into the mold. This was mainly due to the strong fiber orientation (higher number of fibers crossing at particular sections) parallel to the flow direction. The flexural strength of UHPC increased linearly with increased fiber dosage. UHPC mixtures incorporating higher aspect ratio fibers had increased flexural capacity compared to that of those with lower aspect ratio fibers. The flexural strength of UHPC decreased as the specimen size increased.

UHPC exhibits higher bond strength to rebar and fibers owing to its dense micro- and macro-structures. UHPC elements typically require smaller reinforcement due to higher mechanical and durability properties. Smaller concrete cover in UHPC members further reduces the crosssectional dimensions leading towards more economical construction. It was reported that the application of UHPC leads to reducing earthquake design loads due to a decrease in the overall structural weight. Furthermore, UHPC exhibited excellent performance against impact loading and is thus highly desirable in military structures where impact resistance due to blast loading is of concern. UHPC also demonstrated superior behavior against fatigue loading and showed no significant sign of failure after $10^{6}$ load cycles.

UHPC exhibits high durability owing to a substantial decrease in the volume and size of pores. The application of pressure during the initial setting of UHPC specimens also reduced the overall porosity by removing entrapped air and additional water. UHPC shows very low water absorption due to its dense microstructure. The chloride diffusion coefficient of UHPC is significantly lower compared to that of NSC and HSC, leading to reduced corrosion risk. The reduced permeability and porosity of UHPC enables better resistance to freezing-thawing cycles. On the other hand, due to reduced porosity, UHPC structures are more vulnerable to fire and elevated temperatures due to obstruction in the release of vapor pressure, leading to physical damage. However, this issue can be mitigated by the use of polypropylene fibers.

The initial material cost of UHPC is higher than that of NSC due to the very high cement content and steel fiber addition. Globally accepted design provisions need to be 
developed in order to provide confidence to the design engineer in utilizing the high strength and other properties of UHPC. In short, it can be concluded that UHPC can be a sustainable material due to its improved mechanical and durability properties, ecological factors, economical benefits and its recycling ability in various applications.

\section{Open Access}

This article is distributed under the terms of the Creative Commons Attribution 4.0 International License (http:// creativecommons.org/licenses/by/4.0/), which permits unrestricted use, distribution, and reproduction in any medium, provided you give appropriate credit to the original author(s) and the source, provide a link to the Creative Commons license, and indicate if changes were made.

\section{References}

AASHTO T197. (2000). Time of setting of concrete mixtures by penetration resistance. In American Association of State Highway and Transportation Officials, Standard Specifications for Transportation Materials and Methods of Sampling and Testing, Washington, DC.

Abbas, S., Soliman, A., \& Nehdi, M. (2015). Exploring mechanical and durability properties of ultra-high performance concrete incorporating various steel fiber lengths and dosages. Construction and Building Materials, 75, 429-441.

ACI 363R-92. (1997). State-of-the-art report on high-strength concrete (p. 55).

AFGC-SETRA (Association Francaise de Genie Civil-Service d'etudes Techniques des Routes et Autoroutes). (2002). Ultra-high performance fibre-reinforced concretes, recommendations provisoires-interim recommendations ( $\mathrm{p}$. 98).

Ahlborn, T., Peuse, E., Misson, D., \& Gilbertson, C. (2008). Durability and strength characterization of ultra-high performance concrete under variable curing regimes. In Proceedings of the 2nd International Symposium on UltraHigh Performance Concrete, Kassel, Germany (pp. 197-204).

Aitcin, P. (2000). Cements of yesterday and today - concrete of tomorrow. Cement and Concrete Research, 30(9), 1349-1359.

Allena, S., Newtson, M. (2010). Ultra-high strength concrete mixtures using local materials. In Proceedings of International Concrete Sustainability Conference, Tempe, AZ.

Aoude, H., Dagenais, F., Burrell, R., \& Saatcioglu, M. (2015). Behavior of ultra-high performance fiber reinforced concrete columns under blast loading. International Journal of Impact Engineering, 80, 185-202.

Astarlioglu, S., \& Krauthammer, T. (2014). Response of normal-strength and ultra-high-performance fiber-reinforced concrete columns to idealized blast loads. Engineering Structures, 61, 1-12.
ASTM C230. (1998). Standard specification for flow table for use in tests of hydraulic cement (p. 6). ASTM Standard Practice C230, Philadelphia, PA.

ASTM C1202. (2010). Standard test method for electrical indication of concrete's ability to resist chloride ion penetration (p. 7). West Conshohocken, PA: ASTM.

Barnett, J., Millard, G., Tyas, A., \& Schleyer, K. (2010). Blast tests of ultra high performance fibre reinforced concrete panels. Proceeding of Institute of Civil Engineering, Construction Material, 163(3), 127-139.

Bayard, O., \& Ple, O. (2003). Fracture mechanics of reactive powder concrete: Material modeling and experimental investigations. Engineering Fracture Mechanics, 70(7-8), 839-851.

Behloul, M. (1996). Les micro-bètons renforces de fibers. De l'éprouvevette aux structures, XIVèmes Journées de l'AUGC.

Bindiganavile, V., Banthia, N., \& Aarup, B. (2002). Impact response of ultra-high-strength fibre-reinforced cement composite. ACI Materials Journal, 99(6), 543-548.

Bjornstrom, J., Martinelli, A., Matic, A., Borjesson, L., \& Panas, I. (2004). Accelerating effects of colloidal nanosilica for beneficial calcium silicate hydrate formation in cement. Chemical Physics Letters, 392(1-3), 242-248.

Blais, Y., \& Couture, M. (2000). Precast, prestressed pedestrian bridge-world's first reactive powder concrete structure. PCI Journal, 44(5), 60-71.

Bonneau, O., Lachemi, M., Dallaire, E., Dugat, J., \& Aitcin, P. (1997). Mechanical properties and durability of two industrial reactive powder concretes. ACI Materials Journal, 94(4), 286-290.

Bonneau, O., Poulin, C., Dugat, J., Richard, P., \& Aitcin, P. (1996). Reactive powder concretes: From theory to practice. Concrete International, 18(4), 47-49.

Bonneau, O., Vernet, C., Moranville, M., \& Aitcin, P. (2000). Characterization of the granular packing and percolation threshold of reactive powder concrete. Cement and Concrete Research, 30(12), 1861-1867.

Bornemann, R., \& Faber, S. (2004). UHPC with steel- and noncorroding high strength polymer fibres under static and cyclic loading. In Proceedings of the International Symposium on Ultra-High Performance Concrete, Kassel, Germany (pp. 673-681).

Brown, J. (2006). Highway span features UHPC. Civil Engineering, 76(7), 24-26.

CEB-FIP Model Code 90. (1993). Bulletin d'Information, No. 213/214 (p. 460). London, UK: Thoma Telford Ltd.

Chan, Y., \& Chu, S. (2004). Effect of silica fume on steel fibre bond characteristics in reactive powder concrete. Cement and Concrete Research, 34(7), 1167-1172.

Cheyrezy, M. (1999). Structural applications of RPC. Concrete, 33(1), 20-23.

Cheyrezy, M., Maret, V., \& Frouin, L. (1995). Microstructural analysis of RPC (reactive powder concrete). Cement and Concrete Research, 25(7), 1491-1500.

Cheyrezy, M., Roux, N., Behloul, M., Ressicaud. A., \& Demonte, A. (1998). Bond strength of reactive powder concrete. In Proceedings of the 13th FIP Congress on 
Challenges for Concrete in the Next Millennium, Amsterdam, The Netherlands (Vol. 1, pp. 65-68).

Collepardi, S., Coppola, L., Troli, R., \& Collepardi, M. (1997). Mechanical properties of modified reactive powder concrete. American Concrete Institute, SP 173-01 (p. 22).

Cwirzen, A. (2007). The effect of the heat-treatment regime on the properties of reactive powder concrete. Advances in Cement Research, 19(1), 25-33.

Cwirzen, A., Penttala, V., \& Cwirzen, K. (2008). The effect of heat treatment on the salt freeze-thaw durability of UHSC. In Proceedings of the 2nd International Symposium on Ultra High Performance Concrete, Kassel, Germany (pp. 221-230).

Dowd, W., \& Dauriac, C. (1996). Reactive powder concrete. Construction Specifier, 49(12), 47-52.

Droll, K. (2004). Influence of additions on ultra-high performance concretes-grain size optimization. In Proceedings of the International Symposium on UHPC, Kassel, Germany (pp. 285-301).

El-Dieb, A. (2009). Mechanical, durability and microstructural characteristics of ultrahigh-strength self-compacting concrete incorporating steel fibers. Materials and Design, 30, 4286-4292.

Fadzil, A., Norhasri, M., Hamidah, M., Zaidi, M., \& Faizal, J. (2013). Alteration of nano metakaolin for ultra high performance concrete. In Proceedings of the International Civil and Infrastructure Engineering Conference, Malaysia (pp. 887-894).

Faizal, J., Hamidah, M., Norhasri, M., Noorli, I., \& Hafez, M. (2015). Chloride permeability of nanoclayed ultra-high performance concrete. In CIEC 2014, Springer, Singapore (pp. 613-623).

Falikman, V., Vajner, A., \& Zverev, I. (2012). New photocatalytic cementitious composites containing modified titanium dioxide nanoparticles. In Proceedings of the $3 \mathrm{rd}$ International Symposium on UHPC and Nanotechnology for High Performance Construction Materials, Kassel, Germany 2012 (pp. 147-152).

Farnam, Y., Mirdamadi, A., \& Shekarchi, M. (2008). Experimental investigation of impact behavior of high strength fiber reinforced concrete panels. In Proceedings of the 2nd International Symposium on Ultra-High Performance Concrete, Kassel, Germany (pp. 751-758).

Fehling, E., Schmidt, M., \& Stuerwald, S. (Eds.). (2008). Second International Symposium on Ultra High Performance Concrete, Kassel, Germany (p. 902).

Fennis, S., Walraven, J., \& Uijl, J. (2009). The use of particle packing models to design ecological concrete. Heron, 54(2-3), 185-204.

Fitik, B., Niedermeier, R., \& Zilch, K. (2008). Fattigue behavior of ultra-high performance concrete under cyclic stress reversal loading. In Proceedings of the 2nd International Symposium on Ultra-High Performance Concrete, Kassel, Germany (pp. 529-536).

Franke, L., Schmidt, H., \& Deckelmann, G. (2008). Behavior of ultra-high performance concrete with respect to chemical attack. In Proceedings of the 2nd International Symposium on Ultra-High Performance Concrete, Kassel, Germany (pp. 453-460).

Gao, R., Liu, Z., Zhang, L., \& Stroeven, P. (2006). Static properties of reactive powder concrete beams. Key Engineering Materials, 302(303), 521-527.

Geisenhansluke, C., \& Schmidt, M. (2004). Methods for modeling and calculation of high density packing for cement and filler in UHPC. In Proceedings of the International Symposium on Ultra-High Performance Concrete, Kassel, Germany (pp. 303-312).

Ghafari, E., Arezoumandi, M., Costa, H., \& Julio, E. (2015a). Influence of nano-silica addition on durability of UHPC. Construction and Building Material, 94, 181-188.

Ghafari, E., Bandarabadi, M., Costa, H., \& Julio, E. (2012). Design of UHPC using artificial neural networks. In 10th International Symposium on Brittle Matrix Composites, Warsaw, Poland (p. 9).

Ghafari, E., Bandarabadi, M., Costa, H., \& Julio, E. (2015b). Prediction of fresh and hardened state properties of UHPC comparative study of statistical mixture design and an artificial neural network model. Journal of Materials in Civil Engineering, 27(11), 1-11.

Ghafari, E., Costa, H., \& Julio, E. (2015c). Statistical mixture design approach for eco-efficient UHPC. Cement and Concrete Composite, 55, 17-25.

Ghafari, E., Costa, H., \& Julio, E. (2015d). Critical review on eo-efficient ultra high performance concrete enhanced with nano materials. Construction and Building Material, 101(1), 201-208.

Ghafari, E., Costa, H., Julio, E., Portugal, A., \& Duraes, L. (2012). Optimization of UHPC by adding nanomaterials. In Proceedings of the 3rd International Symposium on UHPC and Nanotechnology for High Performance Construction Materials, Kassel, Germany (pp. 71-78).

Ghafari, E., Costa, H., Julio, E., Portugal, A., \& Duraes, L. (2014a). The effect of nanosilica addition on flowability, strength and transport properties of ultra high performance concrete. Material and Design, 59, 1-9.

Ghafari, E., Hugo, C., \& Julio, E. (2014b). RSM-based model to predict the performance of self-compacting UHPC reinforced with hybrid steel micro-fibers. Construction and Building Material, 66, 375-383.

Graybeal, B. (2006). Material property characterization of ultrahigh performance concrete. In FHWA-HRT-06-103, U.S. Department of Transportation (p. 176).

Graybeal, B. (2007). Compressive behaviour of ultra-high-performance fibre-reinforced concrete. ACI Materials Journal, 104(2), 146-152.

Graybeal, B., \& Davis, M. (2008). Cylinder or cube: strength testing of $80-200 \mathrm{MPa}(11.6-29 \mathrm{ksi})$ ultra-high performance fibre-reinforced concrete. ACI Materials Journal, 105(6), 603-609.

Graybeal, B., \& Hartmann, J. (2003). Strength and durability of ultra-high performance concrete. In Concrete Bridge Conference (p. 20).

Grunberg, J., \& Ertel, C. (2012). A triaxial fatigue model of ultra-high performance concrete (UHPC). In Proceedings 
of the 3rd International Symposium on UHPC and Nanotechnology for High Performance Construction Materials, Kassel, Germany (pp. 603-610).

Grunberg, J., Lohaus, L., Ertel, C., \& Wefer, M. (2008). Multi axial and fatigue bahvior of ultra-high performance concrete. In Proceedings of the 2nd International Symposium on Ultra-High Performance Concrete, Kassel, Germany (pp. 485-494).

Guvensoy, G., Kocaturk, A., \& Yerlikaya, M. (2004). Mechanical behaviour of high performance steel fibre-reinforced cementitious composites under cyclic loading condition. In Proceedings of the International Symposium on UHPC, Kassel, Germany (pp. 649-660).

Habel, K. (2004). Structural behaviour of elements combining ultra-high performance fibre-reinforced concretes (UHPFRC) and reinforced concrete. PhD Thesis 3036, Swiss Federal Institute of Technology Lausanne, Switzerland (p. 222).

Habel, K., Viviani, M., Denarie, E., \& Bruehwiler, E. (2006). Development of the mechanical properties of an ultra-high performance fiber reinforced concrete. Cement and Concrete Research, 36, 1362-1370.

Hajek, P., \& Fiala, C. (2008). Environmentally optimized floor slabs using UHPC-contribution to sustainable building. In Proceedings of the 2nd International Symposium on Ultra-High Performance Concrete, Kassel, Germany (pp. 879-886).

Hassan, A., Jones, S., \& Mahmud, G. (2012). Experimental test methods to determine the uniaxial tensile and compressive behavior of ultra-high performance fiber reinforced concrete (UHPFRC). Construction and Building Materials, 37, 874-882.

Heinz, D., \& Ludwig, H. (2004). Heat treatment and the risk of DEF delayed ettringite formation in UHPC. In Proceedings of the International Symposium on UHPC, Kassel, Germany (pp. 717-730).

Herold, G., \& Muller, H. (2004). Measurement of porosity of ultra-high strength fibre reinforced concrete. In Proceedings of the International Symposium on Ultra-High Performance Concrete, Kassel, Germany (pp. 685-694).

Holschemacher, K., Weibe, D., \& Klotz, S. (2004). Bond of reinforcement in ultra-high strength concrete. In Proceedings of the International Symposium on UHPC, Kassel, Germany (pp. 375-387).

Holschemacher, K., Wieße, D., \& Klotz, S. (2005) Bond of reinforcement in ultra high- strength concrete. In Seventh International Symposium on Utilization of High Strength High Performance Concrete (Vol. 1, pp. 513-528).

Huang, Z., \& Cao, F. (2012). Effects of nano-materials on the performance of UHPC. Materials Reviews, 26(9), 136-141.

Ingo, S., Jurgen, S., \& Ollver, M. (2004). Effect of mixing and placement methods on fresh and hardened ultra-high performance concrete. In Proceeding of Ultra High Performance Concrete, Kassel, Germany (pp. 575-586).

Juanhong, L., Shaomin, S., \& Lin, W. (2009). Durability and micro-structure of reactive powder concrete. Journal of Wuhan University of Technology Material, 24(3), 506-509.

Jun, P., Taek, K., Tae, K., \& Wook, K. (2008). Influence of the ingredients on the compressive strength of UHPC as a fundamental study to optimize the mixing proportion. In
Proceedings of the 2nd International Symposium on UltraHigh Performance Concrete, Kassel, Germany (pp. 105-112).

Kamen, A., Denarie, E., Sadouki, H., \& Bruhwiler, E. (2009). UHPFRC tensile creep at early age. Materials and Structures, 42, 113-122.

Kang, S., Lee, Y., Park, Y., \& Kim, J. (2010). Tensile fracture properties of an ultra-high performance fiber reinforced concrete (UHPFRC) with steel fibers. Composite Structures, 92(1), 61-71.

Kazemi, S., \& Lubell, A. (2012). Influence of specimen size and fibre content on mechanical properties of ultra-high performance fibre-reinforced concrete. ACI Materials Journal, 109(6), 675-684.

Kim, S., Park, J., Kang, S., \& Ryu, G. (2008). Effect of filling method on fibre orientation and dispersion and mechanical properties of UHPC. In Proceedings of the 2nd International Symposium on Ultra High Performance Concrete, Kassel, Germany (pp. 185-192).

Kooiman, A. (2000). Modelling steel fibre-reinforced concrete for structural design. PhD Thesis, Department of Structural and Building Engineering, Delft University of Technology, Delft, The Netherlands (p. 184).

Korpa, A., \& Trettin, R. (2007). Nanoscale pozzolans for improving ultra-high performance cementitious binders. Cement International, 5(1), 74-83.

Kreiger, E., Ahlborn, T., Harris, D., \& Silva, H. (2012). Characterization of the fracture behavior of UHPC under flexural loading. In Proceedings of the 3rd International Symposium on UHPC and Nanotechnology for High Performance Construction Materials, Kassel, Germany (pp. 411-418).

Lappa, E., Braam, C., Walraven, J. (2004). Static and fatigue bending tests of UHPC. In Proceedings of the International Symposium on Ultra-High Performance Concrete, Kassel, Germany (pp. 449-458).

Lappa, S., Rene, C., \& Walraven, C. (2006). Flexural fatigue of high and ultra-high strength fiber reinforced concrete. In Proceedings of International RILEM Workshop on High Performance Fiber Reinforced Cementitious Composites in Structural Applications, Ann, Arbor, MI (pp. 509-518).

Larrard, F., \& Sedran, T. (1994). Optimization of ultra-high performance concrete by the use of a packing model. $\mathrm{Ce}$ ment and Concrete Research, 24, 997-1009.

Larrard, F., \& Sedran, T. (2002). Mixture proportioning of high performance concrete. Cement and Concrete Research, 32(11), 1699-1704.

Lee, P., \& Chisholm, D. (2005). Reactive powder concrete. Branz, Study Report No. 146 (p. 29).

Lee, G., Chiu, T., \& Wang, Y. (2005). The study of bond strength and bond durability of reactive powder concrete. Journal of ASTM International, 2(7), 104-113.

Lee, Y., Kang, S., \& Kim, J. (2010). Pullout behaviour of inclined steel fibre in an ultra-high strength cementitious matrix. Construction and Building Materials, 24, 2030-2041.

Li, W., Huang, Z., Zu, T., Shi, C., Duan, W., \& Shah, S. (2015). Influence of nanolimestone on the hydration, mechanical 
strength, and autogenous shrinkage of ultrahigh-performance concrete. Journal of Materials in Civil Engineering, 28(1), 1-9.

Li, H., Liu, G. (2013). Tensile properties of hybrid fiber reinforced reactive powder concrete after expose to elevated temperature. International Journal of concrete Structures and Materials, 1-9.

Li, H., Xiao, G., \& Ou, P. (2004). A study on mechanical and pressure-sensitive properties of cement mortar with nanophase materials. Cement and Concrete Research, 34(3), 435-438.

Lohaus, L., \& Anders, S. (2004). Effects of polymer- and fibre modifications on the ductility, fracture properties and micro crack development of ultra-high performance concrete. In Proceedings of the International Symposium on UHPC, Kassel, Germany (pp. 625-636).

Lohaus, L., \& Elsmeier, K. (2012). Fatigue behaviour of plain and fibre reinforced ultra-high performance concrete. In Proceedings of the 3rd International Symposium on UHPC and Nanotechnology for High Performance Construction Materials, Kassel, Germany (pp. 631-637).

Lohaus, L., \& Ramge, P. (2008). Robustness of UHPC-A new approach for mixture proportioning. In Proceedings of the Second International Symposium on Ultra High Performance Concrete, Kassel, Germany (pp. 113-120).

Ma, J., Orgass, M., Dehn, F., Schmidt, D., \& Tue, N. (2004). Comparative investigations on ultra-high performance concrete with and without coarse aggregates. In Proceedings of the International Symposium on Ultra-High Performance Concrete, Kassel, Germany (pp. 13-15).

Ma, J., \& Schneider, H. (2002). Properties of ultra-high performance concrete. Leipzig Annual Civil Engineering Report (LACER), 7, 25-32.

Maeder, U., Lallemant-Gamboa, I., Chaignon, J., \& Lombard J. (2004). CERACEM a new high performance concrete: characterization and applications. In Proceedings of the International Symposium on Ultra High Performance Concrete, Kassel, Germany (pp. 67-76).

Magureanu, C., Sosa, I., Negrutiu, C., \& Heghes, B. (2012). Mechanical properties and durability of ultra-high performance concrete. ACI Materials Journal, 109, 177-183.

Makita, T., \& Bruhwiler, E. (2013). Tensile fatigue behaviour of ultra-high performance fibre-reinforced concrete. Materials and Structures, 17.

Mao, L., Barnett, J., Begg, D., Schleyer, K., \& Wight, G. (2014). Numerical simulation of ultra high performance fibre reinforced concrete panel subjected to blast loading. International Journal of Impact Engineering, 64, 91-100.

Mao, L., Barnett, S., Tyas, A., Warren, J., Schleyer, G., \& Zaini, S. (2015). Response of small scale ultra high performance fibre reinforced concrete slabs to blast loading. Construction and Building Materials, 93, 822-830.

Maroliya, M. (2012). Bond strength of reactive powder concrete containing steel fibre and silica fume. International Journal of Emerging Technology \& Advanced Engineering, 2(10), $66-68$.

Matte, V., \& Moranville, M. (1999). Durability of reactive powder composites: Influence of silica fume on leaching properties of very low water/binder pastes. Cement and Concrete Research, 21(1), 1-9.

Mehta, K., \& Monteiro, J. (2006). Concrete: Microstructure, properties, and materials (4th ed., p. 659). New York, NY: McGraw-Hill.

Millard, S., Molyneaux, T., Barnett, S., \& Gao, X. (2010). Dynamic enhancement of blast-resistant ultra high performance fibre-reinforced concrete under flexural and shear loading. International Journal of Impact Engineering, 37(4), 405-413.

Millon, O., Riedel, W., Mayrhofer, C., \& Thoma, K. (2012). Failure mechanisms of UHPC components under explosive loading. In Proceedings of the 3rd International Symposium on UHPC and Nanotechnology for High Performance Construction Materials, Kassel, Germany (pp. 583-591).

Morin, V., Tenoudji, F., Feylessoufi, A., \& Richard, P. (2001). Superplasticizer effects on setting \& structuration mechanisms of UHPC. Cement and Concrete Research, 31(1), $63-71$.

Moser, B., Pfeifer, C., \& Stark, J. (2009). Durability and microstructural development during hydration in ultrahigh performance concrete (pp. 87-88). London, UK: Taylor and Francis Group.

Muller, U., Kuhne, H., Fontana, P., Meng, B., \& Nemecek, J. (2008). Micro texture and mechanical properties of heat treated and autoclaved ultra-high performance concrete (UHPC). In Proceedings of the 2nd International Symposium on UHPC, Kassel, Germany (pp. 213-220).

Ngo, T., Mendis, P., \& Krauthammer, T. (2007). Behavior of ultrahigh-strength prestressed concrete panels subjected to blast loading. Journal of Structural Engineering, 133, 1582-1590.

Nguyen, D., Kim, D., Ryu, G., \& Koh, K. (2013). Size effect on flexural behaviour of ultra-high performance hybrid fibrereinforced concrete. Composites, 45, 1104-1116.

Orgass, M., \& Klug, Y. (2004). Fibre-reinforced ultra-high strength concretes. In Proceedings of the International Symposium on ultra-High Performance Concrete, Kassel, Germany (pp. 637-648).

Pansuk, W., Sato, Y., Sato, H., \& Shionaga, R. (2008). Tensile behaviour and fibre orientation of UHPC. In Proceedings of the 2nd International Symposium on UHPC, Kassel, Germany (pp. 161-168).

Park, S., Ryu, G., Koh, K., \& Kim, D. (2014). Effect of shrinkage reducing agent on pullout resistance of highstrength steel fibers embedded in ultra-high-performance concrete. Cement \& Concrete Composites, 49, 59-69.

Perry, V., \& Zakariasen, D. (2004). First use of ultra-high performance concrete for an innovative train station canopy. Concrete Technology Today, 25(2), 1-2.

Pierard, J., \& Cauberg, N. (2009). Evaluation of durability and cracking tendency of ultra-high performance concrete. In Creep, shrinkage and durability mechanics of concrete and concrete structures (pp. 695-700). London, UK: Taylor and Francis Group.

Pierard, J., Dooms, B., \& Cauberg, N. (2012). Evaluation of durability parameters of UHPC using accelerated lab tests. In Proceedings of the 3rd International Symposium on 
UHPC and Nanotechnology for High Performance Construction Materials, Kassel, Germany (pp. 371-376).

Pimienta, P., Mindeguia, J., Simon, A., Behloul, M., Felicetti, R., Bamonte, P., \& Gambarova, P. (2012). Literature review on the behaviour of UHPFRC at high temperature. In Proceedings of the 3rd International Symposium on UHPC and Nanotechnology for high Performance Construction Materials, Kassel, Germany (pp. 549-556).

Racky, P. (2004). Cost-effectiveness and sustainability of UHPC. In Proceedings of the International Symposium on Ultra High Performance Concrete, Kassel, Germany (pp. 797-805).

Rebentrost, M., \& Wight, G. (2008). Experience and applications of ultra-high performance concrete in Asia. In Proceedings of the 2nd International Symposium on UHPC, Kassel, Germany.

Reda, M., Shrive, G., \& Gillott, E. (1999). Microstructural investigation of innovative UHPC. Cement and Concrete Research, 29(3), 323-329.

Reineck, H., \& Greiner, S. (2004). Tests on ultra-high performance fibre-reinforced concrete designing hot-water tanks and UHPFRC-shells. In Proceedings of the International Symposium on Ultra-High Performance Concrete, Kassel, Germany (pp. 361-374).

Richard, P., \& Cheyrezy, M. (1994). Reactive powder concretes with high ductility and 200-800 MPa compressive strength. Concrete technology: Past, present, and future. In Proceedings of $V$. Mohan Malhotra Symposium (pp. 507-518). American Concrete Institute.

Richard, P., \& Cheyrezy, M. (1995). Composition of reactive powder concretes. Cement and Concrete Research, 25, 1501-1511.

Rong, Z., Sun, W., Xiao, H., \& Jiang, G. (2015). Effects of nano- $\mathrm{SiO}_{2}$ particles on the mechanical and microstructural properties of ultra-high performance cementitious composites. Cement and Concrete Composite, 56, 25-31.

Rossi, P. (2005). Development of new cement composite materials for construction. Proceedings of the Institution of Mechanical Engineers, Part L: Journal of Materials Design \& Applications, 219(L1), 67-74.

Rougeau, P., \& Burys, B. (2004). Ultra-high performance concrete with ultrafine particles other than silica fume. In Proceedings of the International Symposium on UHPC, Kassel (pp. 313-325).

Roux, N., Andrade, C., \& Sanjuan, M. (1996). Experimental study of durability of reactive powder concretes. Journal of Materials in Civil Engineering, 8(1), 1-6.

Roy, D., Gouda, R., \& Bobrowsky, A. (1972). Very high strength cement pastes prepared by hot pressing and other high pressure technique. Cement and Concrete Research, 2, 349-366.

Scheydt, C., \& Muller, S. (2012). Microstructure of ultra high performance concrete (UHPC) and its impact on durability. In Proceedings of the 3rd International Symposium on UHPC and Nanotechnology for High Performance Construction Materials, Kassel, Germany (pp. 349-356).

Scheydt, J., Muller, H., \& Herold, G. (2008) Long term behaviour of ultra-high performance concrete under the attack of chlorides and aggressive waters. In Proceedings of the 2nd International Symposium on Ultra-High Performance Concrete, Kassel, Germany (pp. 231-238).

Schleyer, K., Barnett, J., Millard, G., Rebentrost, M., \& Wight, G. (2011). UHPFRC panel testing. Structural Engineering, 89(23/24), 34-39.

Schmidt, D., Dehn, F., \& Urbonas, L. (2004). Fire resistance of ultra-high performance concrete (UHPC) - testing of laboratory samples and columns under load. In Proceedings of the International Symposium on UHPC, Kassel, Germany (pp. 703-715).

Schmidt, M., \& Fehling, E. (2005). Ultra-high-performance concrete: research, development and application in Europe. In 7th International Symposium on Utilization of High Strength High Performance Concrete (Vol. 1, pp. 51-77).

Schmidt, M., Fehling, E., \& Geisenhanslueke, C. (Eds.). (2004). International Symposium on Ultra High Performance Concrete, Kassel, Germany (p. 868).

Schmidt, M., Fehling, E., Glotzbach, C., Frohlich, S., \& Piotrowski, S. (Eds.). (2012). Third International Symposium on UHPC and Nanotechnology for High Performance Construction Materials, Kassel, Germany (p. 1036).

Schmidt, M., Fehling, E., Teichmann, T., Bunje, K., \& Bornemann, R. (2003). Ultra-high performance concrete: Perspective for the precast concrete industry. Concr Precasting Plant Tech., 69(3), 16-29.

Schmidt, M., \& Teichmann, T. (2007). Development of an ultra high performance concrete for the company SW Umwelttechnik. Final report, Kassel, Germany.

Shah, S., \& Weiss, W. (1998). Ultra high strength concrete; Looking toward the future. In ACI Special Proceedings from the Paul Zia Symposium Atlanta, GA.

Shaheen, E., \& Shrive, N. (2006). Optimization of mechanical properties and durability of reactive powder concrete. $A C I$ Material Journal, 103(6), 444-451.

Shakhmenko, G., Korjakins, A., Kara, P., Justs, J., \& Juhnevica, I. (2012). UHPC containing nanoparticles synthesized by sol-gel method. In Proceedings of the 3rd International Symposium on UHPC and Nanotechnology for High Performance Construction Materials, Kassel, Germany (pp. 79-85).

Shi, C., Wu, Z., Xiao, J., Wang, D., Huang, Z., \& Fang, Z. (2015). A review on ultra high performance concrete: Part 1. Raw materials and mixture design. Construction and Building Materials, 101, 741-751.

Shu-hua, L., Li-hua, L., \& Jian-wen, F. (2012). Study on mechanical properties of reactive powder concrete. Journal of Civil Engineering and Construction, 1(1), 6-11.

Skazlic, M., Bjegovic, D., \& Serdar, M. (2008). Influence of test specimens geometry on compressive strength of ultra-high performance concrete. In Proceedings of the 2nd International Symposium on Ultra High Performance Concrete, Kassel, Germany (pp. 295-301).

Sobolev, K., \& Amirjanov, A. (2004). The development of a simulation model of the dense packing of large particulate assemblies. Powder Technology, 141, 155-160.

Soe, K., Zhang, Y., \& Zhang, L. (2013). Impact resistance of hybrid-fiber engineered cementitious composite panels. Composite Structures, 104, 320-330. 
Soutsos, M., Millard, S., \& Karaiskos, K. (2005). Mix design, mechanical properties, and impact resistance of reactive powder concrete (RPC). In International Workshop on High Performance Fibre-Reinforced Cementitious Composites in Structural Applications (pp. 549-560).

Sritharan, S., Bristow, B., \& Perry, V. (2003). Characterizing an ultra-high performance material for bridge applications under extreme loads. In Proceedings of the 3rd International Symposium on High Performance Concrete, Orlando, FL.

Steil, T., Karihaloo, B., \& Fahling, E. (2004). Effect of casting direction on the mechanical properties of CARDIFRC. In Proceedings of the International Symposium on Ultra-High Performance Concrete, Kassel, Germany (pp. 481-493).

Strunge, T., \& Deuse, T. (2008). Special cements for ultra high performance concrete. In Proceedings of the Second International Symposium on Ultra High Performance Concrete, Kassel, Germany (pp. 61-68).

Sun, W., \& Jiao, C. (2011). Experimental study on impact tensile behavior of reactive powder concrete. Journal of Guangzhou University, 10(1), 42-47.

Taghaddos, H., Mahmoudzadeh, F., Pourmoghaddam, A., \& Shekarchizadeh, M. (2004). Prediction of compressive strength behaviour in RPC with applying an adaptive network-based fuzzy interface system. In Proceedings of the International Symposium on Ultra High Performance Concrete, Kassel, Germany (pp. 273-284).

Tai, S., Pan, H., \& Kung, N. (2011). Mechanical properties of steel fiber reinforced reactive powder concrete following exposure to high temperature reaching $800 \mathrm{C}$. Nuclear Engineering and Design, 241(7), 2416-2424.

Talebinejad, I., Iranmanesh, A., Bassam, S., \& Shekarchizadeh, M. (2004). Optimizing mix proportions of normal weight reactive powder concrete with strengths of 200-350 MPa In Proceedings of the International Symposium on UHPC, Kassel, Germany (pp. 133-141).

Tang, C. (2004). High performance concrete-past, present and future. In Proceedings of the International Symposium on UHPC, Kassel, Germany (pp. 3-9).

Teichmann, T., \& Schmidt, M. (2004). Influence of the packing density of fine particles on structure, strength and durability of UHPC. In Proceedings of the 1st International Symposium on Ultra-High Performance Concrete, Kassel Germany (pp. 313-323).

Thomas, M., Green, B., O’Neal, E., Perry, V., Hayman, S., \& Hossack, A. (2012). Marine performance of UHPC at Treat Island. In Proceedings of the 3rd International Symposium on UHPC and Nanotechnology for High Performance Construction Materials, Kassel, Germany (pp. 365-370).

Tuchlinski, D., Heqqer, J., \& Kommer, B. (2006). Studies on prestressed concrete beams made from UHPC. Concrete Precasting Plant and Technology, 72(1), 14-20.

Tue, N., Orgass, M., \& Ma, J. (2008). Influence of addition method of superplasticizer on the properties of fresh UHPC. In Proceedings of the 2nd International Symposium on Ultra-High Performance Concrete, Kassel, Germany (pp. 93-100).
Van, V., \& Ludwig, H. (2012). Proportioning optimization of UHPC containing rice husk ash and ground granulated blast-furnace slag. In Proceedings of the 3rd International Symposium on UHPC and Nanotechnology for High Performance Construction Materials, Kassel, Germany (pp. 197-205).

Vernet, P. (2004). Ultra-durable concretes: Structure at the micro- and nano-scale. Mater Res Soc, 29(5), 324-327.

Voort, T. (2008). Design and field testing of tapered H-shaped ultra high performance concrete piles. Master Thesis, Iowa State University (p. 243).

Walraven, J. (2008). On the way to design recommendations for UHPFRC. In Proceedings of the 2nd International Symposium on Ultra-High Performance Concrete, Kassel, Germany.

Wang, W., Liu, J., Agostini, F., Davy, C., Skoczylas, F., \& Corvez, D. (2014). Durability of an ultra high performance fiber reinforced concrete (UHPFRC) under progressive aging. Cement and Concrete Research, 55, 1-13.

Wang, D., Shi, C., Wu, Z., Xiao, J., Huang, Z., \& Fang, Z. (2015). A review on ultra high performance concrete: Part II. Hydration, microstructure and properties. Construction and Building Materials, 96, 368-377.

Way, R., \& Wille, K. (2012). Material characterization of an ultra-high performance fibre-reinforced concrete under elevated temperature. In Proceedings of the 3rd International Symposium on UHPC and Nanotechnology for High Performance Construction Materials (pp. 565-572).

Wen-yu, J., Ming-zhe, A., Gui-ping, Y., \& Jun-min, W. (2004). Study on reactive powder concrete used in the sidewalk system of the Qinghai-Tibet Railway bridge. In International Workshop on Sustainable Development and Concrete Technology, Beijing, China (pp. 333-338).

Wille, K., Naaman, A., El-Tawil, S., \& Parra-Montesinos, G. (2012). Ultra-high performance concrete and fibre-reinforced concrete: Achieving strength and ductility without heat curing. Materials and Structures, 45, 309-324.

Wille, K., Naaman, A., \& Montesinos, G. (2011). Ultra-high performance concrete with compressive strength exceeding $150 \mathrm{MPa}(22 \mathrm{ksi})$ : a simpler way. ACI Materials Journal, 108(1), 46-54.

Wille, K., \& Parra-Montesinos, G. (2012). Effect of beam size, casting method, and support conditions on flexural behaviour of UHPFRC. ACI Materials Journal, 109(3), 379-388.

Xing, F., Huang, D., Cao, L., \& Deng, L. (2006). Study on preparation technique for low-cost green reactive powder concrete. Key Engineering Materials, 302-303, 405-410.

Heinz D, Dehn F, Urbonas L. Fire resistance of ultra-high performance concrete (UHPC) - testing of laboratory samples and columns under load. In Proceedings of the International Symposium on UHPC, Kassel, Germany (pp. 703-715).

Yang, I., Joh, C., \& Kim, B. (2010). Structural behaviour of ultra-high performance concrete beams subjected to bending. Engineering Structures, 32(11), 3478-3487.

Yazici, H. (2006). The effect of curing conditions on compressive strength of ultra-high strength concrete with high 
volume mineral admixtures. Building and Environment, 42(5), 2083-2089.

Ye, Y., Hu, S., Daio, B., Yang, S., \& Liu, Z. (2012). Mechanical behaviour of ultra-high performance concrete reinforced with hybrid different shapes of steel fibre. In ASCE, CICTP (pp. 3017-3028).

Yoo, D., Park, J., Kim, S., \& Yoon, Y. (2013). Early age setting, shrinkage and tensile characteristics of ultra-high performance fibre-reinforced concrete. Construction and Building Materials, 41, 427-438.

Yu, R., Spiesz, P., \& Brouwers, H. (2014a). Mix design and properties assessment of Ultra-high performance fibre reinforced concrete (UHPFRC). Cement and Concrete Resesearch, 56, 29-39.

Yu, R., Spiesz, P., \& Brouwers, H. (2014b). Mix design and properties assessment of ultra-high performance fibre reinforced concrete (UHPFRC). Cement and Concrete Research, 56, 29-39.
Yu, R., Spiesz, P., \& Brouwers, H. (2014c). Effect of nano-silica on the hydration and microstructure development of ultrahigh performance concrete (UHPC) with a low binder amount. Construction and Building Materials, 65, $140-150$

Yu, R., Spiesz, P., \& Brouwers, H. (2014d). Static properties and impact resistance of a green ultra-high performance hybrid fibre reinforced concrete (UHPHFRC): Experiments and modeling. Construction and Building Materials, 68, $158-171$.

Zanni, H., Cheyrezy, M., Maret, V., Philippot, S., \& Nieto, P. (1996). Investigation of hydration and pozzolanic reaction in reactive powder concrete using Si NMR. Cement and Concrete Research, 26(1), 93-100.

Zheng, Z., Li, Y., \& Wang, Y. (2012). Compressive behaviour of hybrid fiber-reinforced reactive powder concrete after high temperature. Materials and Design, 41, 403-409. 